\title{
Project Managing in Post-Conflict Environments: \\ An Exploration of the Resource Profiles of Sri Lankan Non-Governmental \\ Organizations involved in Development Projects \\ Yogarajah Nanthagopan \& Nigel Williams
}

\begin{abstract}
The aim of this study is to examine the configuration of project resources in organizations operating in a post-conflict country environment using a Resource-Based View (RBV) perspective. Data collection was undertaken using a quantitative survey study of Non-Governmental Organizations (NGOs) involved in development projects in Sri Lanka, which obtained 445 responses. An Exploratory Factor Analysis and subsequent Confirmatory Factor Analysis were performed to identify and confirm the Project Management (PM) resource profile composition of these organizations. The study identified resource profiles incorporated items at the team, organizational and collaborative social resource levels and did not differ significantly by organization type.

This suggests that the current focus of PM RBV research that implicitly uses a competitive advantage derived framework may need to be adapted for contexts such as Post conflict environments. For organizations seeking to deliver projects in developing countries, the findings indicate that relational capacity in the form of a collaborative social resource may be required to adapt team and organizational resources to post conflict environments.
\end{abstract}

Key words: PM Resources, Resource-Based View, Post-Conflict Environment

\section{Introduction}

As conceptualized, the resource based view models organizations as a combination of resources. These resources can be tangible or intangible (sometimes referred to as capabilities). In Project Management, the resource based view has been used to examine the nature and interactions of codified and tacit deployed in project delivery. Early work in this area classified the type and characteristics of resources (Jugdev and Thomas, 2002). Later work examined capabilities (Davies and Brady, 2000) which can support project operational performance, that is the delivery of stakeholder requirements via project or strategic/dynamic capabilities which enable reconfiguration of resources to meet project 
requirements. Subsequent work examined the interaction of resource types such as the co creation of capabilities via interaction of these entities (client and contractor) in the context of complex project delivery (Zerjav et al., 2018). While most of this work has been conducted on firms located in developed countries, in developing countries the research has also explored the capabilities of single firms along with the nature of the project resources deployed by the firms. Further, a significant stream of the RBV in PM research utilizes the conceptualization of Barney (1991) which seeks to identify the competitive advantage of organizations. This approach may not necessarily be adapted into project settings where organizations hold far more complex relationships than oppositional competitive relationships.

Post conflict environments may require organizations to evolve approaches beyond seeking competitive advantage. Post-conflict countries are defined as being the previous setting for an intra-state conflict, such as a civil war. These environments are distinct from the settings in which international development projects may be delivered as armed conflicts may occur in both developed (Northern Ireland) and developing countries (Sri Lanka). The conflict has ended and these countries have begun the decades-long process of establishing peace by achieving milestones, such as the ending of violence, disarmament and facilitating economic recovery (Brown et al., 2011). Unlike other countries, post-conflict countries face the distinctive challenges of community recovery and risk reduction (Collier et al., 2008). Communities hosting former combatants may not wish to work together on regional or national collaborative activities, such as projects (Lake, 2017). A related issue is that the negotiations for employment or contracts to deliver projects may reignite internal conflict in communities composed of former combatants from opposing sides, further increasing the difficulty of project delivery (Barakat and Zyck, 2009). Organizations in these settings who are seeking to deliver projects to communities may require distinct capabilities to meet these requirements. Organizations involved in projects delivered in post conflict countries have additional responsibilities to those involved in traditional international development projects due to the nature of the context. Post conflict countries have a history of violence and latent stakeholder tensions that can return to violence. Organizations need to be sensitive to these challenges and may need to develop resources and capabilities to ensure 
that projects can be delivered without a return to conflict. Specifically, they may adopt communication and collaborative approaches to working in communities where groups may have been previous combatants. Organizations seeking to deliver projects in post-conflict countries may be required to transform internal processes. Evidence from infrastructure projects in Kosovo and Iraq indicate that smaller delivery teams are best for reducing the risk of inflaming local tensions into violence (Pelton and Hunter, 2004). Project teams in these countries may also need to develop reciprocal support relationships with communities in order to deliver activities where formal support from the state may be inconsistent (Kadirova, 2014). For example, civilian organizations may be contracted by foreign military personnel who require adaptation of existing processes to match military procurement practices and success criteria (Kremers et al., 2010). This suggests that firms involved in projects may develop particular resource types individually or develop combinations of resources (resource profiles) to meet these contextual requirements.

Appendix 1 provides a summary of extant work on using the RBV in project firm settings. To date, however, no extant work has examined the project capacities or resource profiles of a category of firms in post conflict countries which can identify the resources/capabilities developed by firms in order to meet the requirements of the external environment. The aim of this study is therefore to empirically examine the configuration of project resources in organizations operating in a post-conflict country environment. In this way, it extends extant work on the RBV (Resource Based View) in Project Management using both the capabilities and resources approach which has examined single firms or projects to identify the resource composition of a population of a specific type of organization (NGOs) in an underexplored country context (post conflict). 
NGOs delivering projects in these environments are required to develop appropriate project management capacities to deliver beneficial outcomes in an environment with damaged infrastructure, divided communities and reduced state capacity. Sri Lanka was the setting for a violent civil war over 30 years (Government of Sri Lanka, 2017). The country is now recovering and local and international Non Governmental Organizations (NGOs) have been participating in the recovery process as well as economic and institutional development (Nanthagopan et al., 2019; DeVotta, 2005). By understanding how NGOs are configured in post-conflict domains like Sri Lanka, the setting of this research, can provide useful insights for project organizations, especially national and international NGOs seeking to work in post-conflict contexts.

This paper provides empirical verification of the types of project capacities that are deployed in a post conflict resource/institutional environment. It suggests that future theoretical development in project management using the resource based view could take a Penrosean perspective which suggests that resource profiles and configurations by firms result in emergent capabilities. These resources can be collective which overcomes the constraint of competitive advantage posed by the Barney approach. While we know of the value of tangible resources and collaborative social resources have been theorized, this approach seeks to provide quantitative empirical evidence of the importance of collaborative social resources as well as their association with other resource types in organizations involved in project delivery.

\section{Literature Review: Post Conflict Country Environment and Project Management} Resources

Unlike it's application in business settings, the Resource-Based View (RBV) application in Project Management does not seek to explain how resources lead to competitive advantage but rather how resources/capabilities are used to perform project activities or reconfigure resources in order to meet complex, evolving stakeholder requirements. Project Management (PM) resources are defined as elements that support project operations, including PM knowledge, skills, systems, processes, culture, tools or techniques (Carnes et al., 2016). RBV research has two dominant paradigms. The first, based on the work of 
Barney (1991), identifies ownership or control of resources with the distinctive characteristics of value, rarity, inimitability and organizational support (VRIO), enabling organizations to perform activities in a manner that distinguishes them from others. This perspective has been applied in project management to classify project resources (Jugdev and Thomas, 2002) into tangible (formal project management methodologies, tools and techniques, databases, project management investments) and intangible (knowledge exchange, mentoring, shadowing). A similar categorization was used to classify project resources in infrastructure (Parker et al., 2015) and resources applied in information system projects (Ghapanchi et al., 2014). Research has also used this perspective to identify the relationship between these resources and project success (Almarri and Gardiner, 2014) and the impact of gender on organizational project performance (Baker et al., 2019).

\subsection{The Resource Based View and Project Capabilities}

Resources have also been identified in the project capabilities approach which are defined as capabilities required for successful project delivery (Davies and Brady, 2000). This work has been extended to identify operational project capabilities and strategic/dynamic supplier project capabilities (Davies and Brady, 2016). Related work has examined these capabilities from the perspective of the project owner (Winch and Leiringer, 2016) and client (Zerjav et al., 2018) in complex projects. Further work has examined the role of owner capabilities in social housing projects in a developing country (Gulino et al., 2020). While this latter work identifies strategic, commercial, governance and transformational capabilities that are required at differing stages of the project life cycle, overall, the project capability school of thought is not conceptually distinct to the VRIO school as applied in projects. Appendix 1 summarises extant research in the RBV and organizations and these studies they posit that the possession or development of particular organizational elements, capabilities in one view and VRIO resources in another, enable the delivery of project outcomes. In international development, the competency perspective of the RBV has been used to conceptualize the development of dynamic NGO competencies in post disaster reconstruction (Von Meding et al., 2009) as well as to empirically examine the competencies of nonprofits involved in post disaster rebuilding projects (Marshall et al., 2017). 
In environments where there are more complex dynamics beyond competition, an alternate conceptualization may be required. Penrose (1959) suggests that distinctive resource combinations provide beneficial outcomes, not individual resource characteristics. In this perspective, organisational activities and outcomes are created by combination and reconfiguration, not merely by ownership of resources (Helfat and Lieberman, 2002; Bryson, 2004; Sowa et al., 2004; Paradkar et al., 2015). Unlike the Barney (1991) view, intangible project resources, such as knowledge, can be integrated and shared across organizations (Newell et al., 2006). Intangible resources in this view are also referred to as capabilities, interpreted as a 'know-how' resource (Bryson, 2004; Sowa et al., 2004; Paradkar et al., 2015; Carnes et al., 2016; Davies et al., 2016). Therefore, the term 'resources' is applied in this study to mean resources and capabilities.

Organizations seeking to deliver projects in Post Conflict countries may need to adapt existing processes in order to compensate for institutional voids and post-conflict tension (Murphy et al., 2018). This implies that organizations may have to develop or acquire new resources in order to perform these adaptation activities. Organizations may also have to work with stakeholders in order to encourage community participation in project evaluation to ensure that trust is maintained in these fragile locations for future activities (Rossignoli et al., 2017). These findings suggest that organizations may have to develop collaborative resources with local stakeholders in order to deliver projects in post-conflict countries. Previous research has identified three types of capacity/resource for project organizations in post conflict countries, which are team, organisational and collaborative social (Nathagopan et al., 2016).

\subsection{Levels of PM Resources}

PM resources have been examined at multiple levels. Initial research identified two resources at the team and organizational levels (Jugdev and Mathur, 2006a). Later work classified resources into three levels: team, organisational and collaborative social/ interorganizational (Nanthagopan et al.,2016). Each level can incorporate both explicit and tacit resources (Mathur et al., 2007; Mahroeian and Forozia, 2012). 


\subsubsection{Team PM Resources}

Existing work has identified tacit and explicit team resources, such as project management practices, project orientation programs, project management expertise, peer learning, field visits, informal meetings, personal coaching, training and mentoring and on-the-job training (Dainty et al., 2005; Jugdev and Mathur, 2006a; Rose et al., 2007; Gorse and Emmitt, 2009; Mathur et al. 2013; Ofori, 2014). Team values and competencies are intuitive knowledge which has been built over some time within the teams (Ghosh and Scott, 2009) and deeply rooted in team values, context, experience and practice (Cook and Brown, 1999).

\subsubsection{Organisational PM resources}

Organisational PM resources incorporate both tacit and explicit elements (Lusthaus et al., 1995; Lusthaus et al., 1999; De Vita et al., 2001; Connolly and Lukas, 2003). Codified organisational PM resources as written documents and transferable means in forms such as audio, video and software. They are generated by the deployment of team PM resources (Cook and Brown, 1999). Previous research has identified: staff capacity-building programs, shared project vision, objectives and policy, effective project coordination and leadership, project organisational structure, effective project communications and processes for sharing knowledge (Gunnarson et al., 2000; White and Fortune, 2002; Jugdev and Mathur, 2006a; Raymond and Bergeron, 2008; Hurt and Thomas, 2009; Richman, 2011; Caniëls and Bakens, 2012; Kaleshovska, 2014).

\subsubsection{Collaborative Social PM Resources}

In addition to team and organizational resources, PM resources comprise formal know-what (explicit) and informal know-how (tacit) elements that provide the organisation with new knowledge (Burn, 2000). These resources are interactive and relational in nature and enable organizations to adapt to the country environment in which they operate (Grant, 1996). These resources are aligned to the Penrose view of the RBV as they may not be owned or controlled by a single organization but can be shared among organizations (Liu and Liu, 2008). In project organizations, Nanthagopan et al. (2016) identified these resources as formal collaborative social PM resources and informal collaborative social PM resources. 
Formal collaborative social resource refers to the ability of the organisation to receive knowledge and advisory recommendations from external networking sources. These include NGOs intra and consortium meetings, project advisory participation from government bodies and from donors, joint project formal interactions and official information releases. Informal collaborative social resource refers to the ability of the organisation to obtain knowledge from informal external interactions. These include networking relations with stakeholders, informal interactions, beneficiary integration in projects, a community of practice through online social networks and project marketing.

\subsection{PM Resources and Organizations}

While research has examined the tools organizations use in development projects (Golini, et al., 2015), little research has examined the impact of country resource environments on project resource profiles of organizations. Project organizations operate within-country contexts and are required to configure internal resources in order to perform activities despite challenges that may exist in external environments. While existing literature identified a 3-level resource structure, this configuration has not been validated using empirical statistical research. Further, project organizations are not homogeneous (Kilby, 2006) and include organizations with international linkages and domestic communityfocused enterprises. These linkages may result in varying firm governance structures. It is not certain if differences in organization types influence the nature of resources owned or controlled by the organisation.

\section{Methodology}

The study aims to examine the configuration of project resources in organizations operating in a post-conflict environment. Therefore, descriptive research and survey design were selected to study the characteristics of project resources in a large number of randomly selected local and international NGOs operating in Sri Lanka. The survey design incorporated a survey instrument, which followed the approach of previous researchers for assessing PM resources in private, public and non-profit organisations (Pact OCA Handbook, 1996; Judgev and Mathur, 2006b). These previous standard questionnaires were already well-tested in the field survey and therefore improve the validity and reliability of 
the present study (Mathers et al., 1998). The researcher selected the 'in-person' method of data collection, which increases the credibility of data collection and makes it possible for respondents to give immediate clarification of vague answers (Bowling, 2005).

\subsection{Sample Selection}

NGOs were selected as the organizations to be examined as they have a long history of providing development activities via projects in post-conflict countries. The organizations selected for this study have been registered with the National Secretariat of NonGovernmental Organizations. Both local and international organizations have been working in post-conflict situations. Comparatively, both organizations have similar characteristics in terms of project operations in the areas in which they operate, types of projects and objective of their operations. In the field, in many cases both organizations work together and hold sector and consortium meetings to discuss their projects and progress. NGO managers share their skills with organizations and many local NGO managers were trained by international organizations. Therefore, the skills of the managers of both organizations are complementary and transferable. However, when considering financial capacity, international organizations have large funds and many local NGOs were funded by international NGOs to implement projects in the communities.

The population is the 1,426 NGOs registered with the National Secretariat for NGOs, of which 1,042 are local and 384 are international NGOs (National Secretariat for NGOs, 2014). For this research, the sample size was 500 local and international NGOs (35\% of the population). The study population consisted of local and international NGOs identified as project organisations; therefore, a stratified random sampling technique was used to select a sample in equal proportion from each stratum to represent the sample to the population. This helps the researcher to select a randomised probabilistic sample from the population and increase the generalisability of the survey findings to the population (Levy and Lemeshow, 2009). The researcher first randomly selected 500 NGOs from each stratum in equal proportions. Subsequently, the researcher contacted 500 NGO managers, one manager from each NGO, who have been directly involved in development projects; for example, Livelihoods, Infrastructure, Relief and Disaster Management and Women 
Development. Of the managers contacted, 463 indicated interest in participating in the survey study; however, 18 questionnaires were eliminated due to incomplete data, leaving 445 questionnaires to be used for further data analysis. The study was conducted in the period from February to November 2015.

\subsection{Sample Characteristics}

Table 1 shows the sample characteristics of the study. The total response from the sample is 445 NGO managers, of which 325 are from local NGOs, and 120 are from international NGOs. Local NGOs managers represent $73 \%$ of the sample size and $27 \%$, represents the international NGOs managers. Education of selected NGO managers is organised as high school, bachelor's degree, postgraduate degree and doctoral degree. The NGO managers holding a bachelor's degree represent $45 \%$ of the sample, with higher education at $32 \%$ and postgraduate degree at $22 \%$. Doctoral degree contributed the least representation $(1 \%)$ in the sample. Some $77 \%$ of NGO managers responded that they had followed PM courses, while 20\% said they had not followed any PM courses and 3\% did not respond. The table further classifies the sample characteristics of local and international NGO managers. 


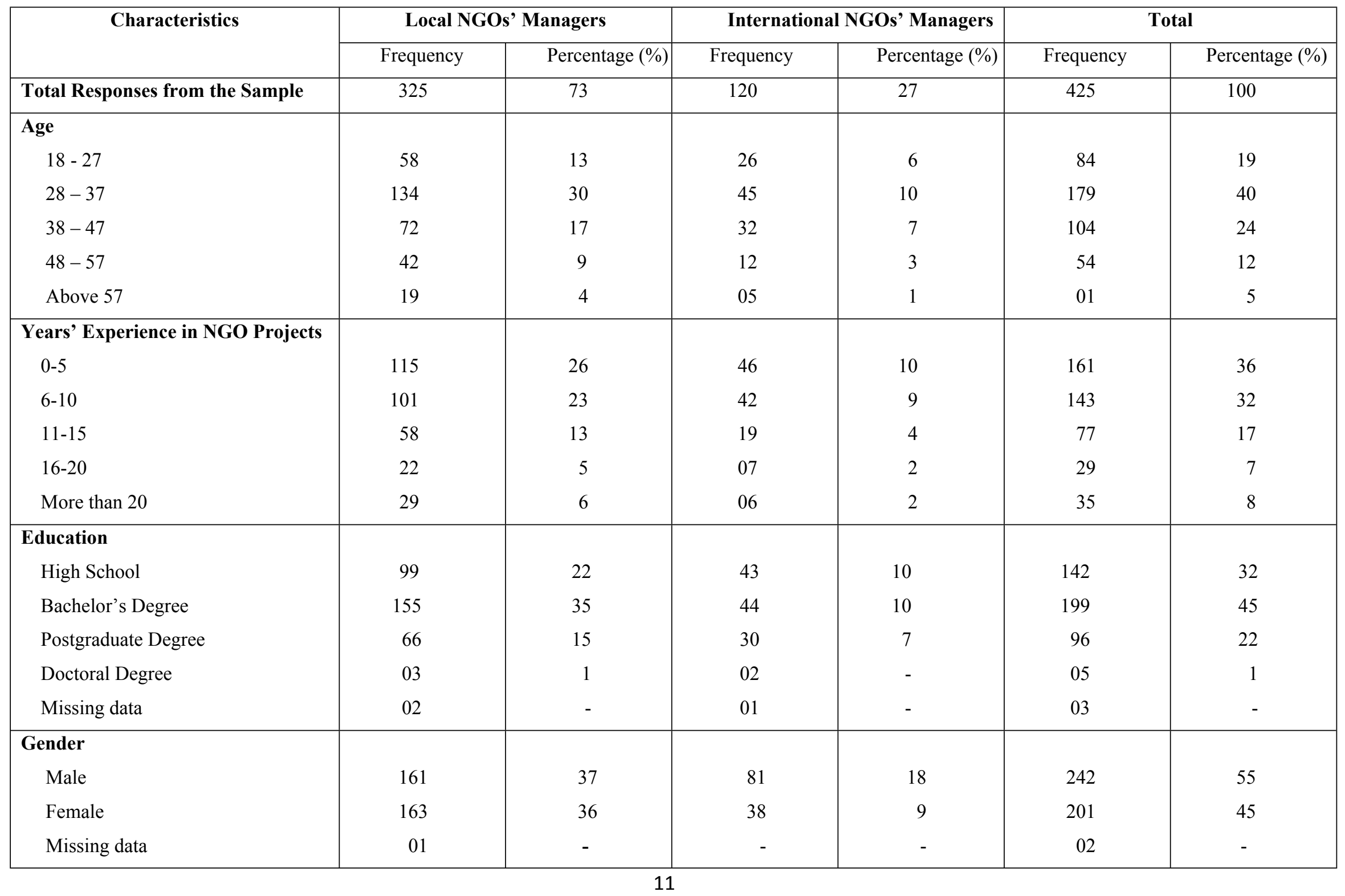




\begin{tabular}{|c|c|c|c|c|c|c|}
\hline \multicolumn{7}{|l|}{ Type of Project } \\
\hline Livelihoods & 57 & 13 & 12 & 3 & 69 & 16 \\
\hline Infrastructure & 25 & 6 & 11 & 2 & 36 & 8 \\
\hline Water and Sanitation & 19 & 4 & 11 & 3 & 30 & 7 \\
\hline Health and Nutrient & 24 & 6 & 14 & 3 & 38 & 9 \\
\hline Training and Education & 49 & 11 & 19 & 4 & 68 & 15 \\
\hline Social Mobilisation & 37 & 8 & 09 & 2 & 46 & 10 \\
\hline Capacity Building & 24 & 5 & 08 & 2 & 32 & 7 \\
\hline Women Development & 19 & 4 & 08 & 2 & 27 & 6 \\
\hline Gender Equity & 16 & 4 & 04 & 1 & 20 & 5 \\
\hline Others & 10 & 2 & 05 & 1 & 15 & 3 \\
\hline \multicolumn{7}{|l|}{$\begin{array}{l}\text { Project Management Courses } \\
\text { Attended }\end{array}$} \\
\hline Yes & 237 & 53 & 105 & 24 & 342 & 77 \\
\hline No & 79 & 18 & 10 & 2 & 89 & 20 \\
\hline Missing data & 09 & 02 & 05 & 1 & 14 & 3 \\
\hline
\end{tabular}

Table 1: Sample Characteristics of the study (N=445, NGO Managers) 


\subsection{Data Analysis}

Two data analysis techniques were used; exploratory factor analysis (EFA) and confirmatory factor analysis (CFA) (Byrne, 2010). Statistical software packages were used to analyse the final survey data. The Statistical Package for Social Sciences (SPSS v16) was used for the preliminary and EFA analyses (Hopkins, 2008) and Analysis of Moment Structures (AMOS v21) was used for the advanced analyses of the measurement model and to confirm the identified factors from the exploratory factor analysis (Byrne, 2013).

EFA is applied either to explore the structure among a set of variables and determine the latent structure or as a data reduction method (Conway and Huffcutt, 2003; Cramer, 2003). In previous studies related to RBV, the EFA technique is applied to identify the latent structure of organisational or PM resources (Jugdev and Mathur, 2006a; Jafari and Rezaee, 2014). In this study, EFA is used to test the concepts and to identify the critical PM resources of NGOs (Lewis-Beck, 1994). CFA is applied to evaluate the overall measurement model based on a priori theory or the results of EFA and it is also widely used to study the associations between a set of observed variables and their underlying latent constructs (Bryne, 2013; Brown, 2014). The CFA technique is applied in previous RBV research to confirm the measurement model of organisational resources (Wahjudono et al., 2013; Jafari and Rezaee, 2014). The present study consists of latent constructs of PM resources and CFA is used to examine the measures of constructs.

Further, a construct validity test is performed to examine how well it measures the construct it claims to be measuring (Brown, 1998; Hair et al., 2006). The study data are ordinal in nature, so are not likely to meet the strict assumptions of the EFA and CFA. Appropriate statistical tests were performed to check the parametric requirements. The researcher used similar tested instruments (questionnaire, survey) to ensure the quality of data collection. Additionally, the dependent latent variables have been tested by previous researchers and performed with parametric tests (Ika et al., 2012). Therefore, this practice has improved the measurement properties (Embretson, 1996; Harwell and Gatti, 2001). 


\subsection{Operational Model}

The PM resources are classified into three levels; team, organisational and collaborative social, with resources and measures in each level explained in Table 2. Measurement of Team PM resources is achieved using Questions Q1 to Q10, Organisational PM uses Questions Q11 to Q20 and Collaborative social PM resources uses Questions Q21 to Q30. The survey instrument is attached in Appendix 1.

\begin{tabular}{|c|c|c|c|}
\hline Concepts & Variables & Indicators & Measure \\
\hline 更 & Team Level & $\begin{array}{l}\text { Casual conversations and informal meetings } \\
\text { Brainstorming sessions } \\
\text { Field visits } \\
\text { On-the-job training } \\
\text { Job shadowing and mentoring } \\
\text { Success and failure stories } \\
\text { Team cohesion and trust } \\
\text { Team values } \\
\text { Team PM expertise } \\
\text { Team best PM practices }\end{array}$ & $\begin{array}{l}\text { Q1 } \\
\text { Q2 } \\
\text { Q4 } \\
\text { Q5 } \\
\text { Q6 } \\
\text { Q7 } \\
\text { Q8 } \\
\text { Q9 } \\
\text { Q10 }\end{array}$ \\
\hline Resources & $\begin{array}{l}\text { Organisation } \\
\text { Level }\end{array}$ & $\begin{array}{l}\text { Effective PM office } \\
\text { PM methodology, standards and process } \\
\text { PM tools and techniques } \\
\text { PM information system } \\
\text { Project monitoring and evaluation mechanism } \\
\text { Staff capacity-building programs } \\
\text { Formal meetings for sharing knowledge } \\
\text { Effective project communications systems and } \\
\text { technology } \\
\text { Defined organisational PM culture } \\
\text { Supportive organisational leadership to PM }\end{array}$ & $\begin{array}{l}\text { Q11 } \\
\text { Q12 } \\
\text { Q13 } \\
\text { Q14 } \\
\text { Q15 } \\
\text { Q16 } \\
\text { Q17 } \\
\text { Q18 }\end{array}$ \\
\hline
\end{tabular}




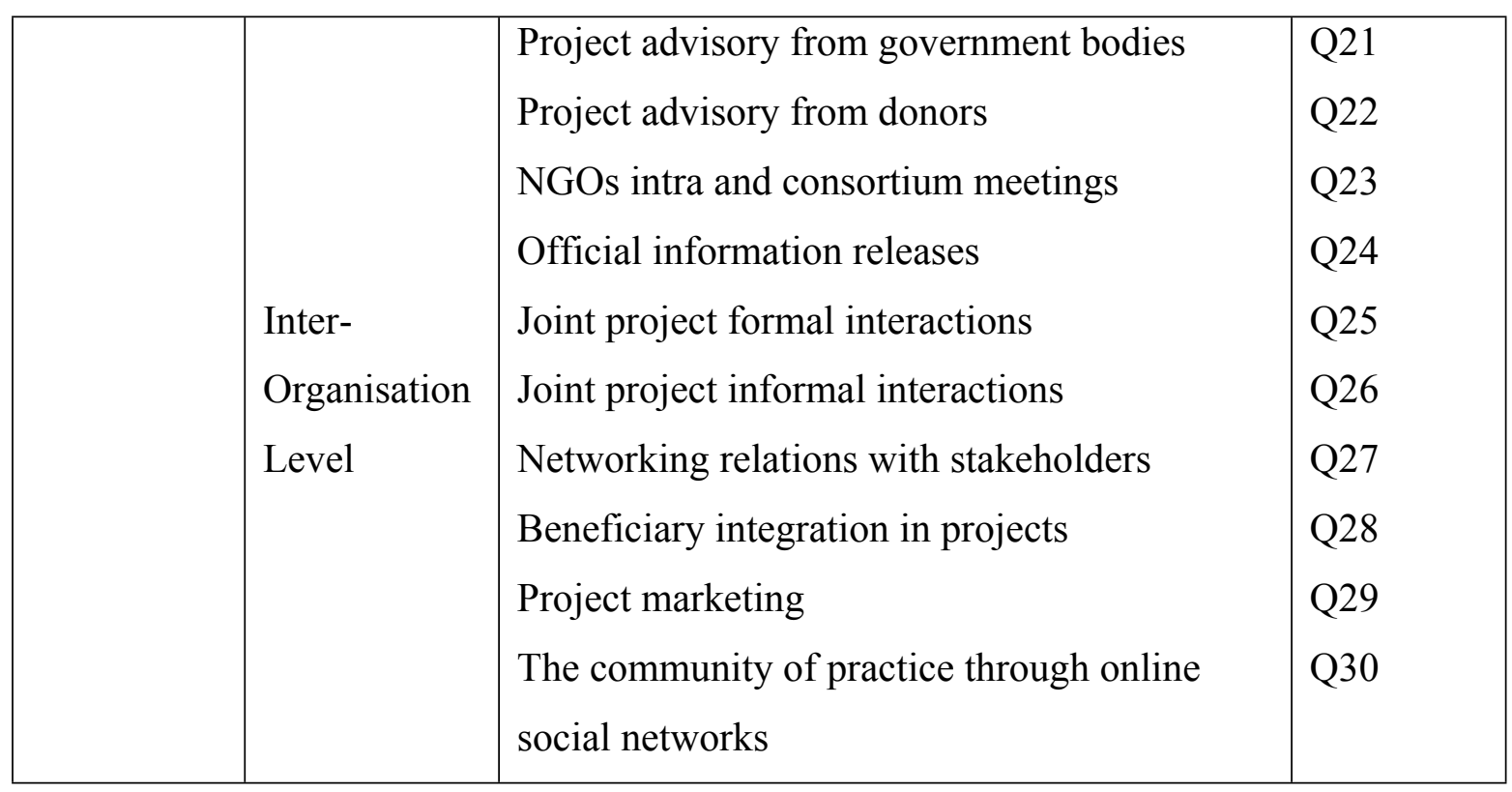

Table 2: Operational Model of PM Resources

\section{Data Analysis}

\subsection{Independent Sample t-test of Local and International NGOs.}

The independent sample t-test is performed for local and international NGOs to establish whether population mean values are equal or not. Table 3 shows the results of the independent sample t-test of all variables of PM resources. The results explain the mean values of all variables (except two) are not significantly different ( $p$ values are greater than 0.05 ) between local and international NGOs. This finding indicates the resource profiles of local and international Organizations do not differ and are the same in a post-conflict environment. Therefore, it is appropriate to integrate the data of local and international NGOs for further multivariate analysis.

\begin{tabular}{|l|c|c|c|c|c|}
\hline \multirow{2}{*}{} & \multicolumn{5}{|c|}{$\mathrm{t}$-test for Equality of Means } \\
\cline { 2 - 6 } & $\mathrm{t}$ & $\mathrm{Df}$ & $\begin{array}{c}\text { Sig. (2- } \\
\text { tailed) }\end{array}$ & $\begin{array}{c}\text { Mean } \\
\text { Difference }\end{array}$ & $\begin{array}{c}\text { Std. Error } \\
\text { Difference }\end{array}$ \\
\hline $\begin{array}{l}\text { Casual Conversations \& } \\
\text { Informal Meetings }\end{array}$ & 1.408 & 445 & .160 & .254 & .180 \\
\hline Brain Storming Sessions & 1.073 & 445 & .284 & .165 & 1.073 \\
\hline Field Visits & 3.596 & 445 & .000 & .521 & 3.596 \\
\hline
\end{tabular}




\begin{tabular}{|c|c|c|c|c|c|}
\hline On-the-Job Training & 1.096 & 445 & .274 & .189 & 1.096 \\
\hline Job Shadowing and Mentoring & .900 & 445 & .369 & .127 & .900 \\
\hline Success and Failure Stories & .957 & 445 & .339 & .130 & .957 \\
\hline Team Cohesion and Trust & .404 & 445 & .686 & .060 & .404 \\
\hline Strong PM Discipline & .478 & 445 & .633 & .070 & .478 \\
\hline Team PM Expertise & 1.338 & 445 & .182 & .192 & 1.338 \\
\hline PM Best Practices & 1.809 & 445 & .071 & .262 & 1.809 \\
\hline PM Office & .735 & 445 & .463 & .107 & .735 \\
\hline $\begin{array}{l}\text { PM Methodology, Standards } \\
\text { and Process }\end{array}$ & .059 & 445 & .953 & .008 & .141 \\
\hline PM Tools and Techniques & .608 & 445 & .544 & .084 & .139 \\
\hline PM Information System & 3.329 & 445 & .001 & .583 & .175 \\
\hline $\begin{array}{l}\text { Monitoring and Evaluation } \\
\text { Mechanism }\end{array}$ & 1.283 & 445 & .200 & .191 & .149 \\
\hline $\begin{array}{l}\text { Staff Capacity Building } \\
\text { programs }\end{array}$ & .984 & 445 & .326 & .153 & .155 \\
\hline $\begin{array}{l}\text { Formal Meetings for Sharing } \\
\text { Knowledge }\end{array}$ & .393 & 445 & .694 & .059 & .150 \\
\hline $\begin{array}{l}\text { Effective Project } \\
\text { Communication }\end{array}$ & 1.459 & 445 & .145 & .214 & .146 \\
\hline Supportive Orgn Culture to PM & -.129 & 445 & .897 & -.018 & .142 \\
\hline Supportive Leadership to PM & .064 & 445 & .949 & .009 & .149 \\
\hline $\begin{array}{l}\text { Project Advisory from } \\
\text { Government Bodies }\end{array}$ & .445 & 445 & .657 & .078 & .175 \\
\hline Project Advisory from Donors & .204 & 445 & .838 & .032 & .159 \\
\hline $\begin{array}{l}\text { NGOs Intra and Consortium } \\
\text { Meetings }\end{array}$ & .556 & 445 & .578 & .090 & .162 \\
\hline Official Information Releases & 1.325 & 445 & .186 & .236 & .178 \\
\hline $\begin{array}{l}\text { Joint Project Formal } \\
\text { Interactions }\end{array}$ & 1.339 & 445 & .181 & .229 & .171 \\
\hline
\end{tabular}




\begin{tabular}{|l|c|c|c|c|c|}
\hline $\begin{array}{l}\text { Joint Project Informal } \\
\text { Interactions }\end{array}$ & -.223 & 445 & .823 & -.037 & .167 \\
\hline Networking with Stakeholders & .869 & 445 & .385 & .137 & .158 \\
\hline $\begin{array}{l}\text { Beneficiary Connections in } \\
\text { Projects }\end{array}$ & 1.248 & 445 & .213 & .167 & .133 \\
\hline Project Marketing events & 1.365 & 445 & .173 & .212 & .155 \\
\hline $\begin{array}{l}\text { Community of Practice through } \\
\text { Social Networks }\end{array}$ & 1.185 & 445 & .237 & .223 & .188 \\
\hline
\end{tabular}

Table 3: Independent Sample t-test of Local and International NGOs

\subsection{Exploratory Factor Analysis (EFA)}

EFA was used to identify critical PM resources at each level since the three levels of PM resources were identified in the literature review. EFA was performed using the Principal Axis Factoring (PAF) method for each proposed factor separately in order to identify the optimum number of items for each factor (Field, 2005) as it is focused on shared variance and is unique to individual measurements (Warner, 2007).

\subsubsection{Item (Indictor) Selection of Team PM Resource}

Ten items (Q1-Q10) are included in the team PM resource. EFA led to the retention of one factor and the eight best items have been selected. Table 4 contains the results of EFA. In the first step, items Q1 and Q4 were eliminated as their factor loadings are less than 0.55. EFA was performed for a second time. During the second run, the researcher identified eight good items with factor loadings greater than 0.55. The Cronbach's alpha value for these eight items is 0.899 , which is greater than the standard value of 0.7 . The total variance explained by the factor is 59\%. The Kaiser-Meyer-Olkin Measure of Sampling Adequacy is 0.917 , which indicates sampling adequacy is superb. The data within this factor returned a significance value of less than 0.001 , which indicates that the data is acceptable for FA. 


\begin{tabular}{|c|c|c|c|c|c|}
\hline \multirow[b]{2}{*}{$\begin{array}{c}\text { Factor } \\
\text { Question } \\
\text { Number }\end{array}$} & \multirow[b]{2}{*}{ Items } & \multicolumn{2}{|c|}{$\begin{array}{c}\text { Step } 1 \\
\text { (10 Items) }\end{array}$} & \multicolumn{2}{|c|}{$\begin{array}{c}\text { Step } 2 \\
\text { (8 Items) }\end{array}$} \\
\hline & & Loadings & $\begin{array}{l}\text { Cronbach } \\
\text { Alpha if } \\
\text { item } \\
\text { deleted }\end{array}$ & Loadings & $\begin{array}{c}\text { Cronbach } \\
\text { Alpha if } \\
\text { item } \\
\text { deleted }\end{array}$ \\
\hline Q1 & $\begin{array}{l}\text { Casual Conversations and } \\
\text { Informal Meetings }\end{array}$ & 0.395 & 0.892 & \multicolumn{2}{|c|}{ Item eliminated } \\
\hline Q2 & Brainstorming Sessions & 0.688 & 0.869 & 0.685 & 0.890 \\
\hline Q3 & Field Visits & 0.639 & 0.871 & 0.610 & 0.896 \\
\hline Q4 & On-the-Job Training & 0.471 & 0.885 & \multicolumn{2}{|c|}{ Item eliminated } \\
\hline Q5 & $\begin{array}{l}\text { Job Shadowing and } \\
\text { Mentoring }\end{array}$ & 0.629 & 0.874 & 0.631 & 0.894 \\
\hline Q6 & Success and Failure Stories & 0.759 & 0.866 & 0.764 & 0.884 \\
\hline Q7 & Team Cohesion and Trust & 0.771 & 0.865 & 0.775 & 0.883 \\
\hline Q8 & Team PM Values & 0.803 & 0.863 & 0.814 & 0.879 \\
\hline Q9 & Team PM Expertise & 0.718 & 0.868 & 0.721 & 0.887 \\
\hline Q10 & Best PM Practices & 0.809 & 0.862 & 0.817 & 0.879 \\
\hline $\begin{array}{l}\text { Cronbach' } \\
\text { Eigen Valı } \\
\text { Percentage } \\
\text { Kaiser-Me } \\
\text { Sampling }\end{array}$ & $\begin{array}{l}\text { Alpha } \\
\text { Variance Explained } \\
\text { rer-Olkin Measure of } \\
\text { dequacy. }\end{array}$ & $\begin{array}{c}5.124 \\
51.241 \\
0.920\end{array}$ & 0.883 & $\begin{array}{c}4.722 \\
59.024 \\
0.917\end{array}$ & 0.899 \\
\hline
\end{tabular}

Table 4: Factor Matrix: Team PM Resource of NGOs

\subsubsection{Organisational PM Resource}

Ten items, Q11 through Q20, were used to assess organisational PM resource. Table 5 contains the results of EFA. Only one item, Q14, had a factor loading value of less than 0.55 and nine indicators were selected to proceed to the next stage of CFA. The Kaiser- 
Meyer-Olkin Measure of Sampling Adequacy value of 0.939 shows the sampling adequacy is excellent, and the significance value of less than 0.001 indicates that the data is acceptable for FA. 


\begin{tabular}{|c|c|c|c|c|c|}
\hline \multirow[b]{2}{*}{$\begin{array}{c}\text { Factor } \\
\text { Question } \\
\text { Number }\end{array}$} & \multirow[b]{2}{*}{ Items } & \multicolumn{2}{|c|}{$\begin{array}{c}\text { Step } 1 \\
\text { (10 Items) }\end{array}$} & \multicolumn{2}{|c|}{$\begin{array}{c}\text { Step } 2 \\
\text { (9 Items) }\end{array}$} \\
\hline & & Loadings & $\begin{array}{c}\text { Cronbach } \\
\text { Alpha if } \\
\text { item } \\
\text { deleted }\end{array}$ & Loadings & $\begin{array}{c}\text { Cronbach } \\
\text { Alpha if } \\
\text { item } \\
\text { deleted }\end{array}$ \\
\hline Q11 & PM Office & 0.731 & 0.896 & 0.739 & 0.907 \\
\hline Q12 & $\begin{array}{l}\text { PM Methodology, Standards } \\
\text { and Process }\end{array}$ & 0.771 & 0.894 & 0.774 & 0.905 \\
\hline Q13 & PM Tools and Techniques & 0.799 & 0.892 & 0.797 & 0.903 \\
\hline Q14 & PM Information System & 0.432 & 0.916 & \multicolumn{2}{|c|}{ Item Eliminated } \\
\hline Q15 & $\begin{array}{l}\text { Project Monitoring and } \\
\text { Evaluation Mechanism }\end{array}$ & 0.692 & 0.898 & 0.687 & 0.910 \\
\hline Q16 & $\begin{array}{l}\text { Staff Capacity-Building } \\
\text { Programs }\end{array}$ & 0.688 & 0.898 & 0.686 & 0.910 \\
\hline Q17 & $\begin{array}{l}\text { Formal Meetings for Sharing } \\
\text { Knowledge }\end{array}$ & 0.722 & 0.896 & 0.727 & 0.907 \\
\hline Q18 & $\begin{array}{l}\text { Effective Project } \\
\text { Communication System and } \\
\text { Technology }\end{array}$ & 0.740 & 0.895 & 0.741 & 0.906 \\
\hline Q19 & $\begin{array}{l}\text { Defined Organisational PM } \\
\text { Culture }\end{array}$ & 0.756 & 0.895 & 0.764 & 0.905 \\
\hline Q20 & Supportive Leadership to PM & 0.773 & 0.892 & 0.760 & 0.905 \\
\hline Cronbach' & Alpha & & 0.907 & & 0.916 \\
\hline Eigen Valu & & 5.605 & & 5.404 & \\
\hline Percentage & Variance Explained & 56.055 & & 60.050 & \\
\hline $\begin{array}{l}\text { Kaiser-Me } \\
\text { Adequacy. }\end{array}$ & er-Olkin Measure of Sampling & 0.936 & & 0.939 & \\
\hline
\end{tabular}

Table 5: Factor Matrix: Organisational PM Resource of NGOs 


\subsubsection{Best Item (Indictor) Selection of Collaborative Social PM Resource}

Ten items, Q21 through Q30, were used to assess collaborative social PM resource. Two indicators, Q24 and Q30, were eliminated as their factor loadings were less than 0.55. The Kaiser-Meyer-Olkin Measure of sampling adequacy is 0.862 , which shows sampling adequacy is good and the significance value of less than 0.001 indicates that the data is suitable for FA. Table 6 contains the results of EFA. 


\begin{tabular}{|c|c|c|c|c|c|}
\hline \multirow[b]{2}{*}{$\begin{array}{c}\text { Factor } \\
\text { Question } \\
\text { Number }\end{array}$} & \multirow[b]{2}{*}{ Items } & \multicolumn{2}{|c|}{$\begin{array}{c}\text { Step } 1 \\
\text { (10 Items) }\end{array}$} & \multicolumn{2}{|c|}{$\begin{array}{c}\text { Step } 2 \\
\text { (8 Items) }\end{array}$} \\
\hline & & Loadings & $\begin{array}{c}\text { Cronbach } \\
\text { Alpha if } \\
\text { item } \\
\text { deleted }\end{array}$ & Loadings & $\begin{array}{c}\text { Cronbach } \\
\text { Alpha if } \\
\text { item } \\
\text { deleted }\end{array}$ \\
\hline Q21 & $\begin{array}{l}\text { Project Advisory from } \\
\text { Government Bodies }\end{array}$ & 0.561 & 0.825 & 0.571 & 0.845 \\
\hline Q22 & $\begin{array}{l}\text { Project Advisory from } \\
\text { Donors }\end{array}$ & 0.695 & 0.814 & 0.699 & 0.831 \\
\hline Q23 & $\begin{array}{l}\text { NGOs Intra and Consortium } \\
\text { Meetings }\end{array}$ & 0.687 & 0.812 & 0.678 & 0.833 \\
\hline Q24 & $\begin{array}{l}\text { Official Information } \\
\text { Releases }\end{array}$ & 0.279 & 0.850 & \multicolumn{2}{|c|}{ Item Eliminated } \\
\hline Q25 & $\begin{array}{l}\text { Joint Projects Formal } \\
\text { Interactions }\end{array}$ & 0.577 & 0.821 & 0.567 & 0.845 \\
\hline Q26 & $\begin{array}{l}\text { Joint Projects Informal } \\
\text { Interactions }\end{array}$ & 0.612 & 0.820 & 0.615 & 0.839 \\
\hline Q27 & $\begin{array}{l}\text { Networking with } \\
\text { Stakeholders }\end{array}$ & 0.725 & 0.812 & 0.725 & 0.829 \\
\hline Q28 & $\begin{array}{l}\text { Beneficiary Integration in } \\
\text { Projects }\end{array}$ & 0.675 & 0.817 & 0.676 & 0.835 \\
\hline Q29 & Project Marketing Events & 0.706 & 0.813 & 0.704 & 0.832 \\
\hline Q30 & $\begin{array}{l}\text { The Community of Practice } \\
\text { through Online Social } \\
\text { Networks }\end{array}$ & 0.442 & 0.837 & Item $\mathbf{E}$ & iminated \\
\hline
\end{tabular}




\begin{tabular}{|l|c|c|c|c|}
\hline Cronbach's Alpha & & 0.837 & & 0.854 \\
Eigen Value & 4.310 & & 4.011 & \\
Percentage Variance Explained & 43.102 & & 50.133 & \\
Kaiser-Meyer-Olkin Measure of & 0.873 & & 0.862 & \\
Sampling Adequacy. & & & & \\
\hline
\end{tabular}

Table 6: Factor Matrix: Collaborative Social PM Resource of NGOs

\subsection{Confirmatory Factor Analysis (CFA)}

CFA was used to determine whether the data fits the proposed hypothesised structure of PM resources (Cramer, 2003). Model fit can be achieved in two steps (Hair et al., 2006). The first is the overall assessment of model fit and the second is the construct validity that investigates how well the concepts are designed for measurement. The objective of the measurement model extends beyond examining the relationships between the latent factors to warranting that the individual latent constructs are adequate for investigating the relevant concepts (Fornell and Larcker, 1981; Hair et al., 2006).

Kline (2005) notes that convergent validity and discriminant validity are important measures for estimating a construct. In general, the construct validation process participates in deriving the measurement model with the presence of both convergent and discriminant validity (Liao et al., 2007). Convergent validity is the extent to which items of the latent construct share a proportion of variance (Anderson and Gerbing, 1988; Hair et al., 2006). This is measured by considering factor loadings, construct reliability and average variance extracted (Fornell and Larcker, 1981; Hair et al., 2006). CR and average variance extracted were calculated using Validity Master (Microsoft Office Excel 2010) (Fornell and Larcker, 1981).

\subsubsection{Summary of Comparison of Measurement Model Specifications for PM Resources (Goodness-of-fit Indices of CFA Models)}

In this section, the researcher compares the four alternative models of PM resources and finally identifies the best model of PM resources based on measurement results. Three latent factors are drawn, namely, team PM resources (TPR), organisational PM resources 
(OPR) and collaborative social PM resources (CPR). Appendix 2 shows the measurement results of the first three alternative CFA models.

Table 7 contains a summary of the results for goodness-of-fit indices among the four models of PM resources. The normed chi-square decreased gradually from Model 1 (3.140) to Model 2 (2.742), to Model 3 (2.210) and Model 4 (1.782). Next, the RMSEA decreased through the models (Model $1-0.069$, Model $2-0.063$, Model $3-0.52$ and Model $4-$ 0.042). Lastly, the CFI increased across the models (Model 1 - 0.909, Model 2 - 0.948 , Model 3 - 0.969 and Model 4 - 0.985). These values indicate that Model 4 is a better fit than the previous models (Carmines and McIver, 1981; Wheaton, 1987; MacCallum et al., 1996; Hu and Bentler, 1999). Finally, parsimonious measures of AGFI increased gradually from Model 1 (0.831) to Model 2 (0.884), to Model 3 (0.927) and Model 4 (0.950). However, the PNFI shows slight variations as this measure was adjusted to losses in degrees of freedom over Models 1 to 4 (Mulaik et al., 1989).

\begin{tabular}{|c|l|l|l|l|}
\hline Indices & Model 1 & Model 2 & Model 3 & Model 4 \\
\hline Absolute Measures & & & & \\
\hline Chi-square & 854.1 & 362.0 & 192.2 & 90.82 \\
\hline Degree of freedom & 272 & 132 & 87 & 51 \\
\hline Normed Chi-square & 3.140 & 2.742 & 2.210 & 1.782 \\
\hline GFI & 0.859 & 0.911 & 0.947 & 0.967 \\
\hline RMSEA & 0.069 & 0.063 & 0.52 & 0.42 \\
\hline P-Close & $<0.05$ & $<0.05$ & $>0.05$ & $>0.05$ \\
\hline SRMR & 0.051 & 0.041 & 0.037 & 0.031 \\
\hline Incremental Measure & & & & \\
\hline NFI & 0.872 & 0.922 & 0.945 & 0.966 \\
\hline NNFI (TLI) & 0.899 & 0.940 & 0.963 & 0.980 \\
\hline CFI & 0.909 & 0.948 & 0.969 & 0.985 \\
\hline Parsimony Measure & & & & \\
\hline AGFI & 0.831 & 0.884 & 0.927 & 0.950 \\
\hline
\end{tabular}




\begin{tabular}{|c|l|l|l|l|}
\hline PNFI & 0.791 & 0.795 & 0.783 & 0.746 \\
\hline Fitting Summary & Poor Fit & $\begin{array}{l}\text { Mediocre } \\
\text { Fit }\end{array}$ & Good Fit & Excellent Fit \\
\hline
\end{tabular}

Table 7: Summary of Comparison of Goodness-of-fit Indices

\subsubsection{Final Validated CFA Mode01 4: Three Levels of PM Resources}

A complete description of Models 1 to 4 is presented in Appendix 2. Model 4 was created by fixing the over-estimation and minimising the high cross-loading indicators (MacCallum et al., 1996). Each factor consists of four indicators. Team PM resources consist of items Q2, Q6, Q7 and Q8; organisational PM resources consists of items Q11, Q12, Q13 and Q18; and collaborative social PM resources consists of Q22, Q23, Q27 and Q29.

The results for absolute fit indices show the normed chi-square ( $\left.\chi^{2} / \mathrm{df}\right)$ value of 1.782 , GFI is 0.967 , RMSEA is 0.042, p-close value is greater than 0.05, and SRMR is 0.031. The incremental indices results reveal a NFI of 0.966, a TLI of 0.980 and a CFI of 0.985. Parsimonious fit indices results indicate that AGFI is 0.950 and PNFI is 0.746. The normed chi-square value is less than two and the other three indices show good values which confirm the model fits well (Wheaton, 1987; $\mathrm{Hu}$ and Bentler, 1999; Byrne, 2010). Therefore, this model is accepted. (See Figure 1 and Table 8). 


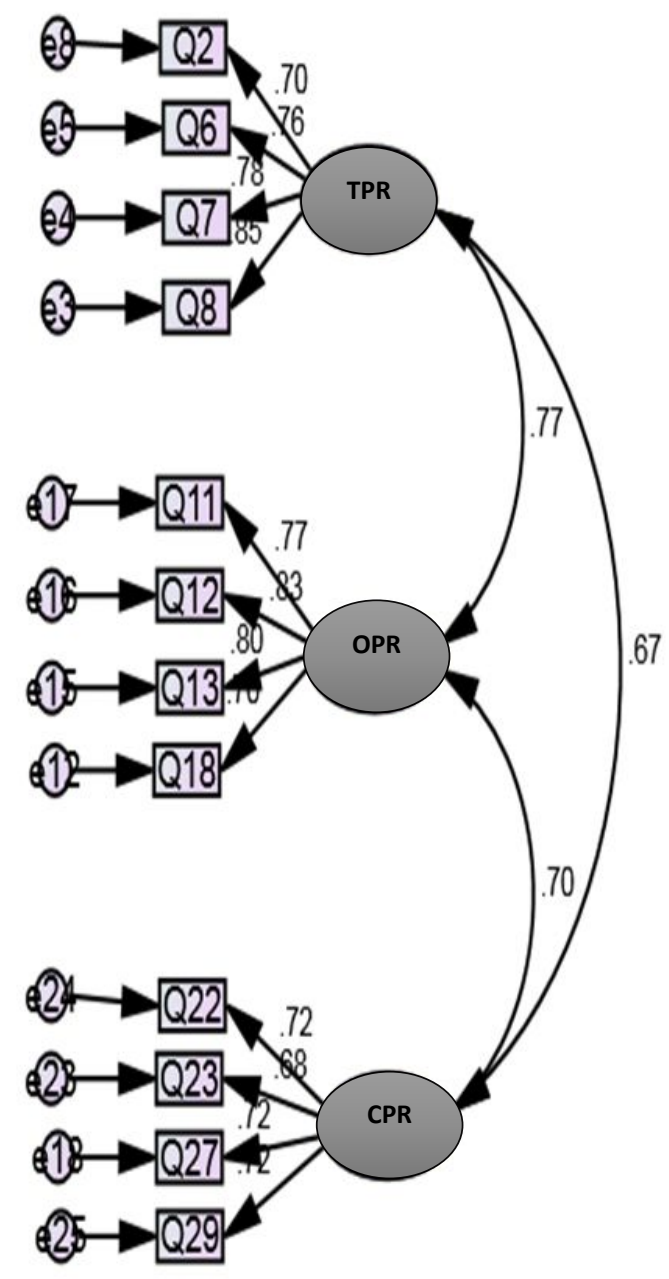

Figure 1: CFA Model 4

\begin{tabular}{|c|c|c|c|c|}
\hline \multirow[t]{2}{*}{ Construct } & \multirow[t]{2}{*}{ Item } & \multicolumn{3}{|c|}{ Standardised } \\
\hline & & TPR & OPR & CPR \\
\hline \multirow{4}{*}{$\begin{array}{l}\text { Team PM } \\
\text { Resource } \\
\text { (TPR) }\end{array}$} & Q2 & 0.70 & & \\
\hline & Q6 & 0.76 & & \\
\hline & Q7 & 0.78 & & \\
\hline & $\mathrm{Q} 8$ & 0.85 & & \\
\hline \multirow{4}{*}{$\begin{array}{l}\text { Organisational } \\
\text { PM Resource } \\
\text { (OPR) }\end{array}$} & Q11 & & 0.77 & \\
\hline & Q12 & & 0.83 & \\
\hline & Q13 & & 0.80 & \\
\hline & Q18 & & 0.70 & \\
\hline \multirow{4}{*}{$\begin{array}{l}\text { Collaborative } \\
\text { Social PM } \\
\text { Resource } \\
(\text { CPR }) \\
\end{array}$} & Q22 & & & 0.72 \\
\hline & Q23 & & & 0.68 \\
\hline & Q27 & & & 0.72 \\
\hline & Q29 & & & 0.72 \\
\hline $\begin{array}{l}\text { Average } \\
\text { Variance } \\
\text { Extracted } \\
\text { (AVE) }\end{array}$ & & 0.60 & 0.61 & 0.50 \\
\hline $\begin{array}{l}\text { Construct } \\
\text { Reliability } \\
\text { (CR) }\end{array}$ & & 0.86 & 0.86 & 0.80 \\
\hline $\begin{array}{l}\text { Absolute Fit } \\
\text { Index }\end{array}$ & \multicolumn{4}{|c|}{$\begin{array}{l}\chi^{2}=90.82, \mathrm{df}=51, \chi^{2} / \mathrm{df}= \\
1.782, \mathrm{GFI}=0.967, \\
\text { RMSEA }=0.42, \mathrm{p} \text {-close }> \\
0.05, \mathrm{SRMR}=0.031\end{array}$} \\
\hline $\begin{array}{l}\text { Incremental } \\
\text { Fit Index }\end{array}$ & \multicolumn{4}{|c|}{$\begin{array}{l}\mathrm{NFI}=0.966, \mathrm{TLI}=0.980 \\
\mathrm{CFI}=0.985\end{array}$} \\
\hline $\begin{array}{l}\text { Parsimony Fit } \\
\text { Index }\end{array}$ & \multicolumn{4}{|c|}{$\begin{array}{l}\text { AGFI }=0.950, \text { PNFI }= \\
0.746\end{array}$} \\
\hline
\end{tabular}

Table 8: Estimates for the CFA Model 


\subsection{Standardised Factor Loading of Items of PM Resources}

The independent sample t-test (as discussed in section 4.1) finding revealed there is no significant difference between the PM resource for local and international NGOs. The standardised factor loading of items in all three levels of PM resources of both combined local and international NGOs tabulated in table 9.

\begin{tabular}{|l|c|}
\hline Items in Three Levels of PM Resources & Standardised Factor Loadings ( $\left.\mathbf{r}^{\mathbf{2}}\right)$ \\
\hline Team PM Resources & 0.70 \\
\hline Brainstorming Sessions & 0.78 \\
\hline Success and Failure stories & 0.79 \\
\hline Team Cohesion and Trust & 0.82 \\
\hline Team PM Values & 0.77 \\
\hline Organisational PM Resources & 0.82 \\
\hline Effective PM Office & 0.80 \\
\hline PM Methodology, Standards and Process & 0.72 \\
\hline PM Tools and Techniques & 0.71 \\
\hline $\begin{array}{l}\text { Effective Project Communication Systems and } \\
\text { Technology }\end{array}$ & 0.73 \\
\hline Collaborative Social PM Resources & \\
\hline Project Advisory from Donors & \\
\hline NGOs Intra and Consortium Meetings & \\
\hline Networking with Stakeholders & \\
\hline Project Marketing Events & \\
\hline
\end{tabular}

*Significance at 0.001 level

Table 9: Standardised Factor Loadings - Items in Three Levels of PM Resources 


\subsection{Findings}

\subsection{Team PM Resource}

Previous Project Management and NGO research identified a range of team resources. The EFA and CFA confirmed four items (Table 9) as the most important team PM elements with high standardised regression estimates $\left(\mathrm{r}^{2}\right)$; those identified resources are brainstorming sessions, success and failure stories, team cohesion and trust, and team values.

Brainstorming sessions are tacit since the knowledge gathered cannot be fully documented or articulated (Leonard-Barton, 1992; Egbu, 2004; Jugdev and Mathur, 2006b). Research in private sector organizations has identified the know-how resource as important (Jugdev and Mathur, 2006b; Mathur et al., 2007; Jugdev et al., 2013). Findings in this study (standardised factor loading $\left(\mathrm{r}^{2}\right)=0.70, \mathrm{p}<0.001$ ) suggests that it is also a critical resource in team PM resource in NGOs. For organizations in this study, these tacit resources may be complementary to providing team resources in an emerging market context for project organizations. Similarly, discussing success and failure stories can be considered a tacit asset as discussions held in the events cannot be fully documented. Previous research emphasised this is the knowledge resource of organisations for effectively sharing knowledge (Cameron, 2007; Ritchie, 2011). Team members can jointly develop this knowhow factor (Jugdev and Mathur, 2006b; Mathur et al., 2007; Jugdev et al., 2013). The present study shows that success and failure stories scored a high standardised factor loading $\left(\mathrm{r}^{2}=0.78, \mathrm{p}<0.001\right)$ in team PM resource. Therefore, the findings recommend it as another critical resource in the team PM resource in NGOs.

Existing research highlighted cohesion, trust and shared PM values as key resources in organisations for productive teamwork (Hempel et al., 2009; Mach et al., 2010). While this is rarely discussed in literature as a crucial PM resource, respondents in this study recognised cohesion as a critical resource ( standardised factor loading $\left(\mathrm{r}^{2}\right)=0.79, \mathrm{p}<0.001$ ) and shared PM values (standardised factor loading $\left(\mathrm{r}^{2}\right)=0.82, \mathrm{p}<0.001$ ) as important elements in team PM resources. 


\subsection{Organisational PM Resource}

The literature on private sector organisations discussed a significant number of PM resources identified as important explicit PM resources for organisations (Richman, 2011; Ika and Lytvynov, 2011; Kaleshovska, 2014). The EFA and CFA confirmed four elements are critical for organisational PM resource with high standardised regression estimates $\left(\mathrm{r}^{2}\right)$ and identified these resources as effective PM office, PM methodology, standards and process, PM tools and techniques and effective project communication systems and technology. Table 9 shows the standardised factor loading of each item explained in organisational PM resources.

First, an effective PM office is considered a critical explicit resource in organisational PM resources, a resource that has been extensively discussed in the literature (Hill, 2004; Jugdev and Mathur, 2006a; Hobbs and Aubry, 2007; Martin et al., 2007; Aubry and Hobbs, 2011; Mathur et al., 2013). Further studies revealed that the PM office supports successful project execution and high project performance (Dai and Wells, 2004; Kaleshovska, 2014). The present NGO study shows that effective PM office scored a high standardised factor loading $\left(\mathrm{r}^{2}=0.77, \mathrm{p}<0.001\right)$, confirming the value of this explicit resource in both a developing and developed context by organizations.

Second, PM methodology, standards and process are identified as a key resource in organisational PM resources in the PM literature (Gunnarson et al., 2000; White and Fortune, 2002; Mathur et al., 2007; Fortune et al., 2011; Mathur et al., 2013; Golini and Landoni, 2014). Further, it supports managing quality projects (Milunovic and Filipovic, 2013) and PM success of the organisation (Labuschagne and Steyn, 2010). However, this does not contribute to the project success of an organisation (Wells, 2012). The present study shows that this resource (standardised factor loading $\left(\mathrm{r}^{2}\right)=0.82, \mathrm{p}<0.001$ ) is most explained compared with other resources in organisational PM resources in NGOs and is considered a critical resource for NGOs.

Third, PM tools and techniques are revealed as key organisational PM resources (Fox and Spence, 1998; Thamhain, 1999; Kloppenborg and Opfer, 2002; Jugdev and Mathur, 2006b; Mathur et al., 2007; Benser and Hobbs, 2008; Fortune et al., 2011; Mathur et al., 2013). 
Previous studies revealed that PM tools and techniques contribute highly to successful project operations (White and Fortune, 2002; Patanakulet et al., 2010; Fortune et al., 2011). The present study shows that PM tools and techniques scored a high standardised factor loading $\left(\mathrm{r}^{2}=0.80, \mathrm{p}<0.001\right)$ in the organisational PM resource and is recommended as a critical resource for NGOs.

Finally, effective project communication systems and technology are identified as an important resource in organisational PM resources in the PM literature (Verma, 1995; Mathur et al., 2007; Relich and Banaszak, 2011; Mathur et al., 2013; Cervone, 2014). Further, project communication systems contribute to the quality and productivity of project team and project success of organisations (Relich and Banaszak, 2011; Cervone, 2014). This study recognises this as an important resource for improving effective communication among team members; therefore, the study recognises this as a critical resource (standardised factor loading $\left.\left(\mathrm{r}^{2}\right)=0.72, \mathrm{p}<0.001\right)$ in the organisational PM resources of NGOs. The PM information received very low variance because operating NGOs in Sri Lanka may not use sophisticated project management software.

\subsection{Collaborative Social Resource}

The EFA and CFA selected four items, namely, project advisory from donors, NGOs intra and consortium meetings, networking with stakeholders and project marketing, which were found with high standardised regression estimates $\left(\mathrm{r}^{2}\right)$ as dominant elements of collaborative social PM resources. Table 9 shows the standardised factor loading of each item that explained collaborative social PM resource.

First, project advisory from donors is considered an important collaborative social PM resource. This is an explicit resource since advisory commonly takes place from the donors formally through meetings or written manuals (Agg, 2006; Coston, 1998). This supports the project teams in acquiring donors' expert advice and requirements for executing projects (Pact, 2012). Further, donors' advisory is very helpful for NGO team members for organising their projects effectively (Lipsky and Smith, 1990). Donors share their experience and expertise with the project teams to plan and implement projects well; additionally, they provide much monitoring and evaluation support to project teams, which 
highly support project success in NGOs. The study shows that project advisory from donors scored a high standardised factor loading $\left(\mathrm{r}^{2}=0.73, \mathrm{p}<0.001\right)$ in collaborative social PM resources and is therefore considered a critical resource in NGOs.

Second, NGOs intra and consortium meetings are considered a key resource in collaborative social PM resources. This is an explicit resource since these meetings are usually formal and recorded as documents. The intra and consortium meetings are highly helpful for team members to know PM practices among the NGOs and set common standards for implementing community development projects (Bennett, 2014; Currion and Hedlund, 2011). Further, NGO staff commonly attend consortium and cluster meetings, which helps them to share their project experiences among NGOs' staff members and to learn about every NGO project in their region. Therefore, it is much easier for NGOs to organise their projects among NGOs, as well as share knowledge and skills of project practices to help improve staff capacities of NGOs. The study shows the standardised factor loading of NGOs' intra and consortium meetings is $\mathrm{r}^{2}=0.67(\mathrm{p}<0.001)$ in collaborative social PM resources and is recognised as a critical PM resource for NGOs.

Third, networking relations with stakeholders is revealed as an important resource in collaborative social PM resources. Networking with stakeholders means that project staff members have informal interactions discussing project activities with project stakeholders. This takes place through informal meetings, telephone conversations or other informal events. Findings in this study (standardised factor loading $\left(\mathrm{r}^{2}\right)=0.71, \mathrm{p}<0.001$ ) suggest it is also a critical resource in collaborative social PM resources.

Finally, project marketing is identified as an important resource in collaborative social PM resources. Project marketing events take place through inauguration meetings, awareness programs, home visits, exhibitions, theatre programs and community meetings in NGOs. Mostly, these kinds of event take place formally and stakeholders' views are recorded as documents for project management team discussions. However, whole discussions and subjective feelings of stakeholders cannot be effectively presented as documents in all cases. Therefore, this resource has highly tacit characteristics and is a resource rarely discussed in PM literature within the context of PM resources. However, this study 
recognises this as a critical systemic knowledge-based resource that may facilitate adaptation to external environments (Miller and Shamsie, 1996). The study shows that project marketing events scored a high standardised factor loading $\left(\mathrm{r}^{2}=0.72, \mathrm{p}<0.001\right)$.

\subsection{Discussion}

This paper extends existing work to examine the structure of PM resource profiles in NGOs and makes two contributions to the literature. The first is that it identifies that resource combinations, a Penrose perspective rather than resource types may support operational project cabilities. The second is that it identifies the possible impact of the post conflict country context on the project resources and capabilities of firms.

For the first contribution, earlier work classified project management as a strategic firm asset (Jugdev, 2004), the characteristics of PM resources (Jugdev and Mathur, 2006b) along with the associations between PM resource characteristics and PM process outcomes (Perkins et al., 2019). More recent work has explored the nature of strategic resources in a single sector of organizations (Energy) in a region (Al-Hanshi et al., 2020). This study extends these contributions to identify the resource combinations of tangible and intangible resources in organizations post-conflict country environment. This is in contrast to the Barney (1991) approach that is embedded in the PM literature (Appendix 1) that would suggest specific resource characteristics would be valuable to organizations and provide additional support for the adoption of a Penrose (1959) perspective to the RBV in project management. In the Barney (1991) view, local and international NGOs would have different profiles as they vary in their access to resources that may have distinctive characteristics. Since the findings of this research indicate otherwise, it suggests that resource combinations, a Penrose (1959) perspective, rather than individual resource characteristics, support the delivery of project activities by organizations which is a theoretical contribution to project management research (Müller and Klein, 2018).

For the second contribution, using this Penrosean perspective provides an avenue to identify the possible role of the post conflict country context in shaping organizational resource characteristics and combinations. While research has examined the coevolution of company/customer capabilities within the context of a project and the path of development 
of the capabilities of a project based organization over time, extant research has not identified the role of country environments in shaping the project resources and capabilities of firms. The findings (Table 3) indicate there was little difference in resource profiles between international and local NGOs in Sri Lanka, a post-conflict country. If PM resources were simply generated by the firm, international organizations would have radically different resource profiles to local firms. International firms may have had a higher level of codified PM resources such as Maturity models while local firms may have relied on tacit or informal resources. This extends existing work that has identified operational and dynamic capabilities of project supplier firms by suggesting that these capabilities are present in a number of firms operating in a given setting rather than individual firms involved in complex project delivery (Zerjav et al., 2018).

This finding suggests that the external environment performed a shaping role and required all firms to adapt to the complex patterns of relationships that exist in post-conflict country settings (Millar, 2017). For example, the findings for explicit organizational level PM resources of effective PM offices contradict the findings for team resources, which may reflect the differences between daily interaction with local Sri Lankan communities and managing relationships with external international bodies. Sri Lankan NGOs are also required to maintain interactions with community stakeholders who may prefer relational means of communication and interaction over codified information exchange via documents. NGO teams may rely on relational, informal coordination and communication strategies for working together in the Sri Lankan environment. At the same time, NGOs are required to maintain formal relationships with funding agencies, governments and international bodies who monitor and evaluate their activities. These organizations will require formal updates and codified information resources (Golini et al., 2015).

In a country context where competition may inflame latent tensions, formal project capacities or capabilities may serve a positive signalling role to join collaborative activities, such as large-scale programs rather than a "negative" attempt to demonstrate competitive advantage over rivals (Davies and Giovannetti, 2018). In a post-conflict country, these formal competencies demonstrates a given NGOs investment in resources to support collaboration with stakeholders, such as international military forces who have defined 
structures that require defined project communication and coordination systems. In this way, they enable extended patterns of collaboration with multiple stakeholders without creating conflict in communities.

These ideas are supported by the findings of both networking relations with stakeholders and project marketing both being important collaborative social PM resources. NGO project staff members have informal networking relationships with grassroots level organisations, relevant government departments and beneficiaries. These differing repeated interactions among stakeholders has been recognized in previous research as an approach for establishing working relationships and shaping emergent project outcomes (Missonier and Loufrani-Fedida, 2014). These approaches are valuable as researchers have found that deterministic stakeholder identification and analysis frameworks are of limited value in environments with complex relationships, such as post conflict countries (Jepsen and Eskerod, 2009).

Organizations in this study may have to maintain "dual personalities" that meet the needs of both host communities and external parties. The issue of ambidexterity has been examined from the perspective of intangible resource deployment in IT projects (Turner et al., 2015). The resource profiles identified in this study may provide evidence of socialized control processes in a post-conflict project setting. These adaptations are countrywide as organizations in this study, both local and domestic, develop ambidextrous resource profiles that can serve both local communities and international bodies.

For organizations seeking to deliver projects in developing countries, the findings indicate that organizations seeking to operate in post-conflict environments develop relational collaborative social resources to adapt team and organizational resources to overcome resource and institutional constraints. The findings indicate that in post-conflict country environments, informal internal mechanisms, such as brainstorming sessions and success and failure stories, are used to transfer accumulated experience within organizations (Xue et al., 2016). An analysis at the resource profile level of organizations in this study indicates team PM competencies, such as team best practices, are not a critical element in Sri Lankan organizations, which contrasts with existing findings from the literature (Ofori, 2014). 


\section{Conclusion}

The lessons learnt from NGOs can be of value to other organisations seeking to operate in post-conflict environments. The findings from this research reveal that organizations in Sri Lanka establish resource profiles that meet domestic and external requirements. For the management of these organizations, recognition of the inherent contradictions of this strategy can enable the optimization of resource profiles, improving organizational efficiencies.

Specifically, in team PM resources, brainstorming sessions and success and failure stories are considered knowledge-sharing activities through team interactions that enable stronger sharing of PM knowledge and skills within teams. Team cohesion and trust and team PM values were considered team cultural characteristics, encouraging teams to work together with a common interest and mutual understanding towards project objectives. The management implications of enhanced team resources may result in formalisation of internal processes, such as information sharing and procedures. However, lower reliance on collaborative resources may reduce an organization's ability to engage with the needs of host communities. NGOs may need to explore methodologies, such as Agile, and techniques, such as design thinking, that explicitly incorporate customer/stakeholder feedback. While there is a tendency to consider agile methodologies as the antithesis of formal planning, several hybrid approaches provide both flexibility and oversight (Marques and da Cunha, 2019).

The findings from this research suggest that the emerging management for a stakeholder's perspective may be more appropriate in a post-conflict environment. Similarly, NGOs working collaboratively with others may need to adopt governance strategies that allow flexibility while still providing the monitoring and control required by external bodies. In organisational PM resources, effective PM office, PM methodology, standards and process, PM tools and techniques assist in improving the project operations through providing advice, and appropriate methods and means, respectively. The study confirms the importance of collaborative social PM resources that comprise a mixture of formal and informal knowledge-sharing activities with external bodies. Therefore, for project organizations seeking to deliver outcomes in these contexts, collaborative social PM 
resource is a very significant resource for transferring knowledge across stakeholder networks. At the same time, the collaborative means promotes team members' future project operations through knowledge transfer, not only between immediate participants but also among stakeholders.

Overall, the study has used insights from NGOs involved in international and local development projects to extend current knowledge of PM resources. While NGOs are distinctive, the critical PM resources identified here may be of value to private and public organizations seeking to develop project resource profiles adapted to emerging markets. For these organizations, the development of collaborative social capacities may enable adaptation to a new host environment, supporting the subsequent development of appropriate team and organizational capacities. Organizations may also need to adopt new evaluation approaches that explicitly recognize the dual nature of operating in these environments. Private and Public organizations seeking to work in post conflict environments may need to adapt existing project processes to incorporate participatory evaluation approaches that enable the incorporation of community input. These organizations may also go beyond quantitative metrics to collect qualitative user feedback in the form of narratives and stories.

There may be distinct differences in resource profiles between local and international Private sector organizations, in contrast to the findings of this research. Local organizations may have community relationships and may develop informal resources. They may not develop formal project resources unless they are working with an international client such as a foreign military that requires formal communications. In contrast, international organizations may have to develop collaborative social capacities as they are required to both adapt to the post conflict environment and report to external parties. Further, they may be required to provide accountability for sustainability and other domains that may not yet be widespread practice in post-conflict countries (Thompson and Williams, 2019).

The path of development of these capabilities in international private organizations may be of interest for future research. Thee trajectory of resource profile development may not be linear or deterministic; that is, from informal to formal. Previous research has identified 
that project resource improvement initiatives in Private organizations in Iran may be linked to other broader organisational development activities which may not follow a life-cycle process of development (Kwak et al., 2015).

The findings from this study also provide a theoretical contribution to Project Management research. This work suggests that a Penrosean perspective (as discussed in section 1.1) in which resource combinations, not characteristics, provide value can be considered for theoretical development in project management research. Future project management research could explicitly consider the compatibility and complementarity of project resources deployed by organizations, along with coordination processes that enable resource reconfiguration. 


\section{References}

Agg, C., 2006. Trends in government support for non-governmental organizations. Golden Age of the NGO Behind Us. New York: United Nations Research Institute for Social Development (UNRISD).

Al-Hanshi, M.A.M.O., Ojiako, U. and Williams, T., 2020. Managing strategic resources in petroleum industry projects. Production Planning \& Control, pp.1-18.

Almarri, K. and Gardiner, P., 2014. Application of resource-based view to project management research: supporters and opponents. Procedia-Social and Behavioral Sciences, $119(7), 437-445$.

Anderson, J. C. and Gerbing, D. W., 1988. Structural Equation Modeling in Practice: A Review and Recommended Two-Step Approach. Psychological Bulletin, 103 (3), 411-423. Aubry, M. and Hobbs, B., 2011. A fresh look at the contribution of project management to organizational performance. Project Management Journal, 42 (1), 3-16.

Baker, M., Ali, M. and French, E., 2019. The impact of women's representation on performance in project-based and non-project-based organizations. International Journal of Project Management, 37(7), pp.872-883.

Barakat, S. and Zyck, S.A., 2009. The evolution of post-conflict recovery. Third world quarterly, 30 (6), 1069-1086.

Barney, J. B., 1991. Firm resources and sustained competitive advantage. Journal of Management, 17 (1), 99-120.

Becker, S.O. and Ferrara, A., 2019. Consequences of forced migration: A survey of recent findings. Labour Economics, 59,1-16.

Bennett, J., 2014. Meeting needs: NGO coordination in practice. New York: Routledge.

Besner, C. and Hobbs, B., (2008). Project management practice, generic or contextual: a reality check. Project Management Journal, 39 (1), 16-33.

Bowling, A., 2005. Mode of questionnaire administration can have serious effects on data quality. Journal of Public Health, 27 (3), 281-291.

Brown, C. H., 2014. Survey Instruments Used to Evaluate Foundation-Funded Nonprofit Capacity-Building Programs: Considerations for Organized Philanthropy. The Foundation Review, 6 (2), 5. 
Brown, J. D., 1998. Statistics Corner: Questions and answers about language testing statistics: Reliability and cloze test length. Shiken: JALT Testing \& Evaluation SIG Newsletter, 2 (2), 19-22.

Brown, G., Langer, A. and Stewart, F., 2011. A typology of post-conflict environments. CRPD Working Paper, 1, 1-22.

Bryson, J. M., 2004. Strategic Planning for Public and Nonprofit Organizations: A Guide to strengthening and sustaining organisational achievement. Public Administration Review, 67 (4), 702-717.

Burns, J., 2000. The dynamics of accounting change inter-play between new practices, routines, institutions, power and politics. Accounting, Auditing \& Accountability journal, $13(5), 566-596$.

Byrne, B. M., 2010. Structural equation modeling with AMOS: Basic concepts, applications, and programming. 2nd edition. New York: Routledge.

Byrne, B. M., 2013. Structural equation modeling with AMOS: Basic concepts, applications, and programming. New York: Routledge.

Cameron, D., 2007. The Myth of Mars and Venus. Oxford: Oxford University Press.

Caniëls, M. C. and Bakens, R. J., 2012. The effects of Project Management Information Systems on decision making in a multi project environment. International Journal of Project Management, 30 (2), 162-175.

Carmines, E. G. and McIver, J. P., 1981. Analyzing models with unobserved variables: Analysis of covariance structures. Social Measurement: Current Issues, 65-115.

Carnes, C.M., Chirico, F., Hitt, M.A., Huh, D.W. and Pisano, V., 2016. Resource Orchestration for Innovation: Structuring and Bundling Resources in Growth- and Maturity-Stage Firms. Long Range Planning.

Cervone, H. F., 2014. Effective communication for project success. OCLC Systems and Services: International Digital Library Perspectives, 30 (2), 74-77.

Collier, P., Hoeffler, A. and Söderbom, M., 2008. Post-conflict risks. Journal of Peace Research, 45 (4), 461-478.

Connolly, P. and Lukas, C., 2003. Strengthening Nonprofit Performance: A Founder's Guide to Capacity Building. Fieldstone Alliance. 
Conway, J. M. and Huffcutt, A. I., 2003. A review and evaluation of exploratory factor analysis practices in organizational research. Organizational Research Methods, 6 (2), 147 168.

Cook, S. D. N. and Brown, J. S., 1999. Bridging epistemologies: Between organizational knowledge and organizational knowing. Organization Science, 10 (4), 381-400.

Coston, J. M., 1998. A model and typology of government-NGO relationships. Nonprofit and Voluntary Sector Quarterly, 27 (3), 358-382.

Cramer, D., 2003. Advanced quantitative data analysis. Berkshire: McGraw-Hill Education.

Currion, P. and Hedlund, K., 2011. Strength in numbers: A review of NGO coordination in the field. Geneva: ICVA.

Dai, C. X. and Wells, W. G., 2004. An exploration of project management office features and their relationship to project performance. International Journal of Project Management, 22, 523-532.

Dainty, A. R., Cheng, M. I. and Moore, D. R., 2005. Competency-based model for predicting construction project managers' performance. Journal of Management in Engineering, 21 (1), 2-9.

Davies, A., \& Brady, T. (2000). Organisational capabilities and learning in complex product systems: towards repeatable solutions. Research policy, 29(7-8), 931-953.

Davies, A., \& Brady, T. (2016). Explicating the dynamics of project capabilities. International Journal of Project Management, 34(2), 314-327.

Davies, W.E. and Giovannetti, E., 2018. Signalling experience \& reciprocity to temper asymmetric information in crowdfunding evidence from 10,000 projects. Technological Forecasting and Social Change, 133, 118-131.

De Vita, C. J. and Fleming, C., 2001. Building Capacity in Nonprofit Organizations. Washington, DC: Center on Nonprofits and Philanthropy (CNP). The Urban Institute.

DeVotta, N., 2005. From ethnic outbidding to ethnic conflict: the institutional bases for Sri Lanka's separatist war 1. Nations and Nationalism, 11 (1), 141-159.

Davies, A. and Brady, T., 2016. Explicating the dynamics of project capabilities. International Journal of Project Management, 34(2), pp.314-327.

Davies, A., \& Brady, T. (2000). Organisational capabilities and learning in complex product systems: towards repeatable solutions. Research policy, 29(7-8), 931-953. 
Earnest, J., 2019. Managing projects in war-torn societies: A case study from Kosovo principles, practices and challenges of "project management" in conflict zones. Journal of Management History.

Egbu, C. O., 2004. Managing knowledge and intellectual capital for improved organizational innovations in the construction industry: an examination of critical success factors. Engineering, Construction and Architectural Management, 11 (5), 301-315.

Embretson, S. E., 1996. The new rules of measurement. Psychological Assessment, 8 (4), 341.

Emiliano de Souza, D., Favoretto, C. and Carvalho, M.M., 2021. Knowledge Management, Absorptive and Dynamic Capacities and Project Success: A Review and Framework. Engineering Management Journal, 1-20.

Eskerod, P. and Jepsen, A.L., 2016. Project stakeholder management. Routledge.

Fernie, S., Green, S.D., Weller, S.J. and Newcombe, R., 2003. Knowledge sharing: context, confusion and controversy. International journal of project management, 21(3), pp.177187.

Field, A. P., 2005. Discovering Statistics using SPSS. London: Sage.

Fornell, C. and Larcker, D. F., 1981. Evaluating structural model with unobserved indicators and measurement errors. Journal of Marketing Research, 18 (1), 39-50.

Fortune, J., White, D., Jugdev, K. and Walker, D., 2011. Looking again at current practice in project management. International Journal of Managing Projects in Business, 4 (4), 553 572.

Fox, T. L. and Spence, J. W., 1998. Tools Of The Trade: A survey of project management tools. Project Management Journal, 29 (3), 20-27.

Ghapanchi, A.H., Wohlin, C. and Aurum, A., 2014. Resources contributing to gaining competitive advantage for open source software projects: An application of resource-based theory. International Journal of Project Management, 32 (1), 139-152.

Ghosh, B. and Scott, J. E., 2009. Relational alignment in offshore IS outsourcing. MIS Quarterly Executive, 8 (1), 19-29.

Global Humanitarian Assistance, 2014. Development Initiatives. Bristol: Global Humanitarian Assistance. Available from: http://www.globalhumanitarianassistance .org/report/gha-report-201,4 [Accessed 1 January 2015]. 
Golini, R. and Landoni, P., 2014. International development projects by non-governmental organizations: an evaluation of the need for specific project management and appraisal tools. Impact Assessment and Project Appraisal, 32 (2), 121-135.

Golini, R., Kalchschmidt, M. and Landoni, P., 2015. Adoption of project management practices: The impact on international development projects of non-governmental organizations. International Journal of Project Management, 33 (3), 650-663.

Gorse, C. A. and Emmitt, S., 2009. Informal interaction in construction progress meetings. Construction Management and Economics, 27 (10), 983-993.

Government of Sri Lanka, 2017. Country Overview [online]. Available from:http://www.gov.lk/web/index.php?option=com content\&view=article\&id=197\&Itemi d=373\&lang=en [Accessed 15 July 2017].

Grant, R. M., 1996. Prospering in Dynamically-competitive Environments: Organizational Capability as Knowledge Integration. Organization Science, 7 (4), 375-89

Gulino, M. L., Sergeeva, N., \& Winch, G. (2020). Owner capabilities in social infrastructure projects: towards an expansion of the dynamic capabilities' framework. International Journal of Managing Projects in Business.

Gunnarson, S., Linde, A. and Loid, D., 2000. Is standardisation applicable to project managers of multi-project companies? Paradoxes of project collaboration in the global economy: Interdependences, complexity and ambiguity. Proceedings of the IRNOP IV Conference. Sydney, Australia. 9-12 January 2000, 136-146.

Hair, J. F., Black, W. C., Babin, B. J., Anderson, R. E. and Tatham, R. L., 2006. Multivariate Data Analysis. 6th edition. Upper Saddle River: NJ: Prentice Hall.

Harwell, M. R. and Gatti, G. G., 2001. Rescaling ordinal data to interval data in educational research. Review of Educational Research, 71 (1), 105-131.

Helfat, C. E. and Lieberman, M. B., 2002. The birth of capabilities: market entry and the importance of pre-history. Industrial and Corporate Change, 11 (4), 725-760.

Hempel, P. S., Zhang, Z. X. and Tjosvold, D., 2009. Conflict management between and within teams for trusting relationships and performance in China. Journal of Organizational Behavior, 30 (1), 41-65.

Heyes, A. and Martin, S., 2015. NGO mission design. Journal of Economic Behavior \& Organization, 119, 197-210. 
Hall, M., 2014. Evaluation logics in the third sector. VOLUNTAS: International Journal of Voluntary and Nonprofit Organizations, 25(2), 307-336.

Hill, G. M., 2004. Evolving the project management office: A competency continuum. Information Systems Management, 21 (4), 45-51.

Hobbs, J. B. and Aubry, M., 2007. A multi-phase research program investigating project management offices (PMOs): The results of phase I. Project Management Institute.

Hopkins, W. G., 2008. Research designs: choosing and fine-tuning a design for your study. Sportscience, 12, 12-21.

Hu, L. and Bentler, P. M., 1999. Cutoff Criteria for Fit Indexes in Covariance Structure Analysis: Conventional Criteria versus New Alternatives. Structural Equation Modeling, 6 (1), 1-55.

Hurt, M. and Thomas, J. L., 2009. Building value through sustainable project management offices. Project Management Journal, 40 (1), 55-72.

Ika, L. A., 2012. Project management for development in Africa: Why projects are failing and what can be done about it. Project Management Journal, 43 (4), 27-41.

Ika, L. A., Diallo, A. and Thuillier, D., 2012. Critical success factors for World Bank projects: an empirical investigation. International Journal of Project Management, 30 (1), 105-116.

Ika, L.A. and Donnelly, J., 2017. Success conditions for international development capacity building projects. International Journal of Project Management, 35 (1), 44-63.

Ika, L. A. and Lytvynov, V., 2011. The "management-per-result" approach to international development project design. Project Management Journal, 42 (4), 87-104.

Jafari, M. and Rezaee, F., 2014. The effect of resource based view on sustainable capability advantage. Management Science Letters, 4 (12), 2537-2554.

Jepsen, A.L. and Eskerod, P., 2009. Stakeholder analysis in projects: Challenges in using current guidelines in the real world. International Journal of Project Management, 27 (4), 335-343.

Jugdev, K. (2004). Through the looking glass: Examining theory development in project management with the resource-based view lens. Project Management Journal, 35(3), 1526.

Jugdev, K. and Mathur, G., 2006a. A factor analysis of tangible and intangible project management assets. $4^{\text {th }}$ PMI Research Conference, Montreal, QC, PMI. 
Jugdev, K. and Mathur, G., 2006b. Project management elements as strategic assets: preliminary findings. Management Research News, 29, 604-17.

Jugdev, K. and Thomas, J., 2002. 2002 Student Paper Award Winner: Project Management Maturity Models: The Silver Bullets of Competitive Advantage?. Project Management Journal, 33 (4), 4-14.

Jugdev, K., Mathur, G. and Fung, T., 2011, July. Project management assets and project management performance: Preliminary findings. In 2011 Proceedings of PICMET'11: Technology Management in the Energy Smart World (PICMET), IEEE, 1-7.

Jugdev, K., Perkins, D., Fortune, J., White, D. and Walker, D., 2013. An exploratory study of project success with tools, software and methods. International Journal of Managing Projects in Business, 6 (3), 534-551.

Kaleshovska, N., 2014. Adopting project management offices to exploit the true benefits of project management. Економски Развој, (1-2), 151-165.

Kadirova, D., 2014. Implementation of Post-Conflict Reconstruction and Development Aid Initiatives: Evidence From Afghanistan. Journal of International Development, 26 (6), 887914.

Kilby, P., 2006. Accountability for empowerment: Dilemmas facing non-governmental organizations. World Development, 34 (6), 951-963.

Kline, R. B., 2005. Principles and Practice of Structural Equation Modeling. In: Kenny, D. A., ed. Methodology in the Social Sciences. 2nd Edition. New York: Guilford Press.

Kloppenborg, T. and Opfer, W., 2002. The current state of project management research: trends, interpretations, and predictions. Project Management Journal, 33, 5-18.

Kremers, J., Rietjens, B., Voordijk, H. and De Boer, S.J., 2010. Construction contracting and civil-military interaction. Construction Management and Economics, 28 (8), 871-883.

Kwak, Y. H., Sadatsafavi, H., Walewski, J. and Williams, N. L., 2015. Evolution of project based organization: A case study. International Journal of Project Management, 33 (8), 1652-1664.

Labuschagne, J. T. and Steyn, H., 2010. Development of a project management methodology for the consulting engineering industry. South African Journal of Industrial Engineering, 21 (1), 69-80.

Lake, M., 2017. Building the rule of war: Postconflict institutions and the micro-dynamics of conflict in Eastern DR Congo. International Organization, 71 (2), 281-315. 
Leonard-Barton, D., 1992. Management of technology and moose on tables. Organization Science, 3 (4), 556-558.

Levy, P. S. and Lemeshow, S., 2009. Sampling of Populations: Methods and Applications: Solutions Manual. Wiley-Blackwell.

Lewis-Beck, M. S., 1994. International Handbooks of Quantitative Applications in the Social Sciences. Factor Analysis and Related Techniques. Vol. 5. UK: Sage Publications.

Liao, C., Chen, J. L, and Yen, D. C., 2007. Theory of Planning Behavior (TPB) and Customer Satisfaction in the Continued Use of E-Service: An Integrated Model. Computers in Human Behavior, 23 (6), 2804-2822.

Lipsky, M. and Smith, S. R., 1990. Government provision of social services through nonprofit organisations. Australian National University, Research School of Social Science, Urban Research Unit.

Liu, M. S. and Liu, N. C., 2008. Sources of knowledge acquisition and patterns of knowledge-sharing behaviours - An empirical study of Taiwanese high-tech firms. International Journal of Information Management, 28 (5), 423-432.

Lusthaus, C., Adrien, M., Anderson, G. and Carden, F., 1999. Enhancing Organizational Performance: A Toolbox for Self-assessment. Ottawa, Canada: International Development Research Centre.

Lusthaus, C., Anderson, G. and Murphy, E., 1995. Institutional Assessment: A Framework for Strengthening Organizational Capacity for IDRC's Research Partners. Ottawa, Canada: International Development Research Centre.

MacCallum, R. C., Browne, M. W. and Sugawara, H. M., 1996. Power analysis and determination of sample size for covariance structure modeling. Psychological Methods, 1 (2), 130 .

Mach, M., Dolan, S. and Tzafrir, S., 2010. The differential effect of team members' trust on team performance: The mediation role of team cohesion. Journal of Occupational and Organizational Psychology, 83 (3), 771-794.

Mahroeian, H. and Forozia, A., 2012. Challenges in Managing Tacit Knowledge: A Study on Difficulties in Diffusion of Tacit Knowledge in Organizations. International Journal of Business and Social Science, 3 (19), 303-308. 
Marques, J. and da Cunha, A. M., 2019. ARES: An Agile Requirements Specification Process for Regulated Environments. International Journal of Software Engineering and Knowledge Engineering, 29 (10), 1403-1438.

Marshall, J. T., Rowberry, R. M., \& Esnard, A. M. (2017). Core capabilities and capacities of developer nonprofits in postdisaster community rebuilding. Natural Hazards Review, 18(2), 05016004.

Mathers, N., Fox, N. J. and Hunn, A., 1998. Surveys and Questionnaires. Trent, UK: NHS Executive.

Mathur, G., Jugdev, K. and Fung, T., 2013. Project management assets and project management performance outcomes: Exploratory factor analysis. Management Research Review, 36 (2), 112-135.

Martin, N. L., Pearson, J. M. and Furumo, K., 2007. IS project management: Size, practices and the project management office. Journal of Computer Information Systems, 47 (4), 5260.

Mathur, G., Jugdev, K. and Fung, T., 2007. Intangible project management assets as determinants of competitive advantage. Management Research News, 30 (7), 460-475

Menkhaus, K., 2004. Conflict prevention and human security: issues and challenges. Conflict, Security \& Development, 4 (3), 419-463.

Milunovic, S. and Filipovic, J., 2013. Methodology for quality management of projects in manufacturing industries. Total Quality Management \& Business Excellence, 24 (1-2), 91107.

Millar, G., 2017. For whom do local peace processes function? Maintaining control through conflict management. Cooperation and Conflict, 52 (3), 293-308.

Miller, D. and Shamsie, J., 1996. The resource-based view of the firm in two environments: The Hollywood film studios from 1936 to 1965. Academy of Management Journal, 39 (3), 519-543.

Missonier, S. and Loufrani-Fedida, S., 2014. Stakeholder analysis and engagement in projects: From stakeholder relational perspective to stakeholder relational ontology. International Journal of Project Management, 32 (7), 1108-1122.

Mulaik, S. A., James, L. R., Van Alstine, J., Bennett, N., Lind, S. and Stilwell, C. D., 1989. Evaluation of goodness-of-fit indices for structural equation models. Psychological Bulletin, 105 (3), 430. 
Müller, R. and Klein, G., 2018. What Constitutes a Contemporary Contribution to Project Management Journal? 3-4

Murphy, J., McDowell, S., Braniff, M. and Denyer, D., 2018. Managing contested spaces: public managers, obscured mechanisms and the legacy of the past in Northern Ireland. Environment and Planning C: Politics and Space, 36 (3), 443-459.

Nanthagopan, Y., Williams, N. L. and Page, S., 2016. Understanding the nature of Project Management capacity in Sri Lankan non-governmental organisations (NGOs): A Resource Based Perspective. International Journal of Project Management, 34 (8), 1608-1624.

Nanthagopan, Y., Williams, N. and Thompson, K. (2019), "Levels and interconnections of project success in development projects by Non-Governmental Organisations (NGOs)", International Journal of Managing Projects in Business, Vol. 12 (2), 487-511.

National Secretary for Non-Governmental Organizations, 2014. The Growth of NGOs Sri Lanka. Colombo: National Secretary for Non-Governmental Organizations.

Available from: http://www.ngosecretariat.gov.lk/web/index.php?option=com _content\&view=article\&id=46\&Itemid=27\&lang=en [Accessed 10 December 2014]

Newell, S., Bresnen, M., Edelman, L., Scarbrough, H. and Swan, J., 2006. Sharing knowledge across projects: limits to ICT-led project review practices. Management Learning, 37 (2), 167-185.

Ofori, D., 2014. An Exploratory Study of Project Management Competency in Ghana. Journal of African Business, 15 (3), 197-210.

Pact's Capacity Assessment (OCA) Handbook, 2012. A Practical Guide to the OCA Tool for Practitioners and Development Professionals. Available from: http://pactworld.org/sites/default/files/OCA\%20Handbook_ext.pdf [Accessed 18 March 2019].

Pact's Organizational Capacity Assessment (OCA), (1996). Facilitation Guide. Available from: http://www.csokenya.or.ke/site/uploads/resource/222.pdf [Accessed 8 December 2019].

Paluch, S., Antons, D., Brettel, M., Hopp, C., Salge, T. O., Piller, F. and Wentzel, D., 2019. Stage-gate and agile development in the digital age: Promises, perils, and boundary conditions. Journal of Business Research. 
Papke-Shields, K.E. and Boyer-Wright, K.M., 2017. Strategic planning characteristics applied to project management. International Journal of Project Management, 35(2), 169179.

Paradkar, A., Knight, J. and Hansen, P., 2015. Innovation in start-ups: Ideas filling the void or ideas devoid of resources and capabilities?. Technovation, 41,1-10.

Parker, D. W., Parsons, N. and Isharyanto, F., 2015. Inclusion of strategic management theories to project management. International Journal of Managing Projects in Business.

Patanakul, P., Iewwongcharoen, B. and Milosevic, D., 2010. An empirical study on the use of project management tools and techniques across project life-cycle and their impact on project success. Journal of General Management, 35 (3), 41-65.

Pelton, J. and Hunter, C., 2004, May. Reinstatement of water supplies post-conflict. In Proceedings of the Institution of Civil Engineers-Civil Engineering (Vol. 157, No. 5, 5358). Thomas Telford Ltd.

Penrose, E. T., 1959. The Theory of the Growth of the Firm. New York: Wiley.

Perkins, D., Jugdev, K. and Mathur, G., 2018. Characteristics of project management assets and project management process outcomes: an exploratory factor analysis. International Journal of Information Technology Project Management (IJITPM), 9 (1), 59-77.

Perkins, D., Mathur, G. and Jugdev, K., 2019. Project management resources and outcomes: a confirmatory factor analysis. International Journal of Managing Projects in Business.

Raymond, L. and Bergeron, F., 2008. Enabling the business strategy of SMEs through ebusiness capabilities: A strategic alignment perspective. Industrial Management \& Data Systems, 108 (5), 577-595.

Relich, M. and Banaszak, Z., 2011. Reference model of project prototyping problem. Foundations of Management, 3 (1), 33-46.

Richman, L., 2011. Successful Project Management. 3rd edition. USA, NY: American Management Association.

Ritchie, L. D., 2011. Why the block is the block: Reinforcing community through casual conversation. Metaphor and the Social World, 1 (2), 239-260.

Rose, J., Pedersen, K., Hosbond, J. H. and Kræmmergaard, P., 2007. Management competences, not tools and techniques: A grounded examination of software project management at WM-data. Information and Software Technology, 49 (6), 605-624. 
Rossignoli, C. M., Giani, A., Di Iacovo, F., Moruzzo, R., and Scarpellini, P. (2017). Enhancing participatory evaluation in a humanitarian aid project. Evaluation, 23 (2), 134151.

Sowa, J. E., Selde, S. C. and Sandfort, J. R., 2004. No Longer Unmeasurable? A Multidimensional Integrated Model of Nonprofit organisational effectiveness. Nonprofit and Voluntary Sector Quarterly, 33 (4): 711-728.

Svejvig, P. and Schlichter, B.R., 2020. The long road to benefits management: toward an integrative management model. Project Management Journal, 51(3), 312-327.

Thamhain, H. J., 1999. Emerging project management techniques: a managerial assessment. In: Portland International Conference on Technology and Innovation Management (PICMET'99), Portland, 25-29 July 1999. 363-368.

Thompson, K.M. and Williams, N.L., 2019. A Guide to Responsible Project Management. Turner, N., Maylor, H. and Swart, J., 2015. Ambidexterity in projects: An intellectual capital perspective. International Journal of Project Management, 33 (1), 177-188.

UNDP, 2014. Human Development Report 2014: Sustaining Human Progress: Reducing Vulnerabilities and Building Resilience. New York: United Nations Development Programme. Available from: http://hdr.undp.org/sites/default/files/hdr14-report-en-1.pdf [Accessed 10 January 2015].

Verma, V. K., 1995. Organizing projects for success: The human aspects of project management. Upper Darby, PA: Project Management Institute.

Von Meding, J. K., Oyedele, L., \& Cleland, D. J. (2009). Developing NGO competencies in post-disaster reconstruction: a theoretical framework. Disaster Advances, 2(3), 36-45.

Wahjudono, D. B. K., Ellitan, L. and Otok, B. W., 2013. Confirmatory Factor Analysis on Organization Reputation, Strategic Leadership, and Organization Culture as a ResourcesBased View. Journal of Management Research. 05 (02), 260-268.

Warner, C. D., 2007. Principal Components and Factor Analysis. Available from: http://www.sagepub.com/upm-data/19710_784.pdf(5.5.2014 [Accessed 10 August 2014].

Wells, H., 2012. How Effective Are Project Management Methodologies? An Explorative Evaluation of Their Benefits in Practice. Project Management Journal, 43 (6), 43-58.

Wheaton, B., 1987. Assessment of fit in overidentified models with latent variables. Sociological Methods \& Research, 16 (1), 118-154. 
White, D. and Fortune, J., 2002. Current practice in project management - An empirical study. International Journal of Project Management, 20 (1), 1-11.

Winch, G., \& Leiringer, R. (2016). Owner project capabilities for infrastructure development: A review and development of the "strong owner" concept. International Journal of Project Management, 34(2), 271-281.

World Bank, 2006. Community-Driven Development in the Context of Conflict-Affected Countries: Challenges and Opportunities. Report No. 36425.

Xue, J., Yuan, H. and Shi, B., 2016. Impact of contextual variables on effectiveness of partnership governance mechanisms in megaprojects: Case of Guanxi. Journal of Management in Engineering, 33 (1), 04016034.

Zerjav, V., Edkins, A., \& Davies, A. (2018). Project capabilities for operational outcomes in inter-organisational settings: The case of London Heathrow Terminal 2. International Journal of Project Management, 36(3), 444-459. 
Appendix 1: Summary of Extant Work on Using the RBV in Project Management

\begin{tabular}{|c|c|}
\hline Extant Works of RBV in Project Management & Authors and Year \\
\hline $\begin{array}{l}\text { PM as processes, they do not have physical characteristics as do other organisational resources such as } \\
\text { machineries and buildings. Rather, these processes are based on intangible knowledge assets; explicit } \\
\text { (codified) and tacit knowledge assets also called 'know-what' (codified) and 'know-how' (tacit) }\end{array}$ & $\begin{array}{l}\text { DeFillippi and Arthur, } \\
1998 \\
\text { Fernie et al., } 2003\end{array}$ \\
\hline $\begin{array}{l}\text { To date, PM literature has focused on codified knowledge assets, the findings reveal the tacit PM } \\
\text { knowledge assets in firms. }\end{array}$ & $\begin{array}{l}\text { Ulri and Ulri, } 2000 \\
\text { Kloppenborg and Opfer, } \\
2002\end{array}$ \\
\hline $\begin{array}{l}\text { PM organisational resources include both explicit resources such as policies, rules and standards and tacit } \\
\text { resources such as norms, values, and routines. }\end{array}$ & Ekinge et al., 2000 \\
\hline $\begin{array}{l}\text { PM team resources are defined as explicit (codified) or tacit elements within teams. Tacit PM team } \\
\text { resources consist of items based on informal sharing of knowledge including casual conversations, } \\
\text { mentoring, stories, brainstorming, and shadowing that address ways in which participants exchange tacit } \\
\text { knowledge. }\end{array}$ & Jugdev and Mathur, 2006 \\
\hline $\begin{array}{l}\text { Explicit PM team resources consist of codified knowledge assets for example professional certifications } \\
\text { and written documents of PM practices. }\end{array}$ & Mathur et al., 2007 \\
\hline $\begin{array}{l}\text { the project management stream of research findings indicates that intangible project management assets } \\
\text { such as tacit knowledge, communities of practice, job shadowing and mentoring contribute to } \\
\text { competitive advantage }\end{array}$ & Jugdev et al., 2007; \\
\hline
\end{tabular}




\begin{tabular}{|c|c|}
\hline $\begin{array}{l}\text { In project management, explicit knowledge resources take the form of standards, methodologies and } \\
\text { procedures. In project management, tacit knowledge resources take the form of team PM skills, } \\
\text { knowledge-sharing activities and lesson-learning sessions }\end{array}$ & Jugdev et al., 2011 \\
\hline $\begin{array}{l}\text { Organisational PM resources have been defined as the extent to which the PM knowledge is distributed, } \\
\text { as well as the composition of this knowledge. }\end{array}$ & $\begin{array}{l}\text { Mahroeian and Forozia, } \\
2012\end{array}$ \\
\hline $\begin{array}{l}\text { The traditional emphasis in project management has been on tangible resources (e.g. tools and } \\
\text { techniques, templates, software and project management offices). More recent project management } \\
\text { research that builds on RBV and the VRIO framework moves attention to intangible project management } \\
\text { resources. }\end{array}$ & $\begin{array}{l}\text { Mathur et al., 2013, } \\
\text { 2014. }\end{array}$ \\
\hline $\begin{array}{l}\text { The Resource-based View of the firm is a strategic management theory that is widely used by managers } \\
\text { in project management. It allows them to spread resources according to alignment with strategy, to } \\
\text { identify the value of such resources and required capabilities for the competitive advantage of the } \\
\text { organization. }\end{array}$ & $\begin{array}{l}\text { Almarri, } \quad \text { K. and } \\
\text { Gardiner, P., } \\
\text { 2014. }\end{array}$ \\
\hline $\begin{array}{l}\text { RBV emphasizes development of a firm's resource-base and strategic assets, and Resource development } \\
\text { theory focuses on external resources and management of environmental dependencies }\end{array}$ & $\begin{array}{l}\text { Parker, D.W., Parsons, } \\
\text { N. and Isharyanto, F., } \\
\text { 2015. }\end{array}$ \\
\hline $\begin{array}{l}\text { The study identified three levels of PM Capacity: Team PM Capacity, Organizational PM Capacity and } \\
\text { Collaborative Social PM Capacity, a Capacity that has not yet been identified in the literature which } \\
\text { supports adaptation to the complex, uncertain environments in which some NGOs operate. }\end{array}$ & $\begin{array}{l}\text { Nanthagopan, } \\
\text { Williams, N.L. and Page, } \\
\text { S., } 2016 .\end{array}$ \\
\hline Findings indicate that $\mathrm{PM}$ is & Papke-Shields, K.E. a \\
\hline
\end{tabular}




\begin{tabular}{|c|c|}
\hline $\begin{array}{l}\text { positively correlated with PM success and use of PM tools/techniques. These results suggest that } \\
\text { strategic planning characteristics can be effectively incorporated into a generalized PM framework, } \\
\text { yielding potentially useful insights regarding the relationship of PM behaviors to eventual project } \\
\text { success. }\end{array}$ & $\begin{array}{l}\text { Boyer-Wright, } \\
2017 .\end{array}$ \\
\hline $\begin{array}{l}\text { The PM resources have valuable, rare and inimitable characteristics. This has influence over the project } \\
\text { performance of the organisations. }\end{array}$ & $\begin{array}{l}\text { Perkins, D., Mathur, G. } \\
\text { and Jugdev, K., } 2019 .\end{array}$ \\
\hline $\begin{array}{l}\text { The analysis shows that at the project level, 'Value' and 'Organisational support' attributes of resources } \\
\text { were positively related to competitive advantage and both impacted by dynamic capabilities and } \\
\text { innovative environment. However, the 'Rareness' and 'Inimitability' attributes showed less evolution. } \\
\text { The results suggest a desire by project-oriented organizations to replace the 'Rareness' and 'Inimitability' } \\
\text { attributes within VIRO with two alternative attributes, namely 'Unique exploitation' and 'Timely } \\
\text { availability' of resources. }\end{array}$ & $\begin{array}{l}\text { Al-Hanshi, M.A.M.O., } \\
\text { Ojiako, U. and Williams, } \\
\text { T., } 2020 .\end{array}$ \\
\hline $\begin{array}{l}\text { The theoretical contribution is a contextualized model of public value creation linking resources, } \\
\text { capabilities and public value. The model explains how Benefits Management practices and hence value } \\
\text { can be interrelated in a public healthcare IT system and realized through an action research project. The } \\
\text { resource-based value approach especially identified (the need for) exact metrics. }\end{array}$ & $\begin{array}{l}\text { Svejvig, } \quad \text { P. and } \\
\text { Schlichter, B.R., 2020. }\end{array}$ \\
\hline $\begin{array}{l}\text { Explicit knowledge is more related to project management efficiency and impact on teams, while tacit } \\
\text { knowledge has also been related to present impact on business. The main tools and techniques regarding } \\
\text { knowledge management in project contexts were also identified. }\end{array}$ & $\begin{array}{l}\text { Emiliano de Souza, D., } \\
\text { Favoretto, C. and } \\
\text { Carvalho, M.M., } 2021 .\end{array}$ \\
\hline
\end{tabular}




\section{Appendix 2 - Survey Insrument}

\section{Project Managing in Post-Conflict Environments:}

An Exploration of the Resource Profiles of Sri Lankan NGOs Involved in

\section{Development Projects}

\section{Project Management (PM) Resources}

PM resources can be defined as PM knowledge (explicit/tacit) elements that support effective project operations, including PM knowledge, skills, systems, processes, culture, tools and techniques.

For each question, there are seven (7) possible answers (1- Strongly Disagree, 2Disagree, 3- Somewhat Disagree, 4- Neither agree nor disagree, 5- Somewhat Agree, 6Agree and 7- Strongly Agree) to choose from. Please circle the answer which you believe best fits the projects you have been involved in your organization.

\section{A: Team PM Resources}

Team PM resources consider the PM knowledge and skills that are accumulated and shared within the team to deliver good project outcomes. The PM resources, such as team informal meetings, on-the-job trainings, team trust, and team PM expertise, are collectively known as team PM Resource.

\section{Team PM Resource}
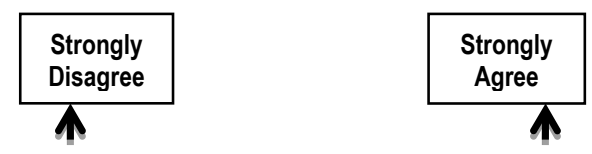

$$
\begin{array}{lllllll}
1 & 2 & 3 & 4 & 5 & 6 & 7
\end{array}
$$

1 We discuss project experiences among our team

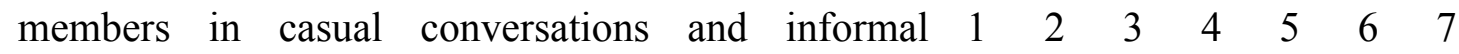
meetings.

2 Our group brainstorming sessions help us to discuss important project problems and find appropriate $\begin{array}{llllllll}1 & 2 & 3 & 4 & 5 & 6 & 7\end{array}$ solutions. 
3 We regularly have field visits to observe and discuss the progress of our projects.

$$
\begin{array}{lllllll}
1 & 2 & 3 & 4 & 5 & 6 & 7
\end{array}
$$

4 On-the-job training is not helpful in improving our PM skills.

$$
\begin{array}{lllllll}
1 & 2 & 3 & 4 & 5 & 6 & 7
\end{array}
$$

5 Job shadowing (learning by observing the works of an expert) and mentoring sessions help to improve our project works.

$\begin{array}{lllllll}1 & 2 & 3 & 4 & 5 & 6 & 7\end{array}$

6 We learn project experiences through discussing $\begin{array}{lllllllll}\text { success and failure stories. } & 1 & 2 & 3 & 4 & 5 & 6 & 7\end{array}$

7 Our team members are always working with mutual $\begin{array}{llllllll}\text { understanding and trust. } & 1 & 2 & 3 & 4 & 5 & 6 & 7\end{array}$

8 Our team values promote strong PM discipline.

$$
\begin{array}{lllllll}
1 & 2 & 3 & 4 & 5 & 6 & 7
\end{array}
$$

9 Our team has very good expertise in applying PM $\begin{array}{lllllllll}\text { knowledge, skills, tools and techniques. } & 1 & 2 & 3 & 4 & 5 & 6 & 7\end{array}$

10 We always abide by best PM practices. $\quad \begin{array}{llllllll} & 1 & 2 & 3 & 4 & 5 & 6 & 7\end{array}$

\section{B: Organizational PM Resource}

Organisational PM resource is the PM knowledge and skills that are incorporated and shared within the organization. The PM resources, such as PM office, methodology, standards, processes, tools, techniques, and formal knowledge sharing activities, are collectively known as organizational PM resource. 


\section{Organizational PM Resource}

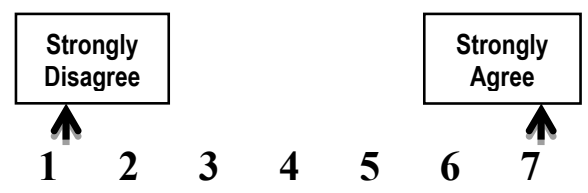

11 We have an effective PM office/unit which supports all of the ways to implement projects effectively and efficiently.

$\begin{array}{lllllll}1 & 2 & 3 & 4 & 5 & 6 & 7\end{array}$

12 We have sound PM methodology, standards and $\begin{array}{llllllll}\text { processes when it comes to managing our projects. } & 1 & 2 & 3 & 4 & 5 & 6 & 7\end{array}$

13 We effectively use PM tools and techniques to manage our projects.

$\begin{array}{lllllll}1 & 2 & 3 & 4 & 5 & 6 & 7\end{array}$

14 Our PM information system is not sound to effectively provide information among our team members.

$\begin{array}{lllllll}1 & 2 & 3 & 4 & 5 & 6 & 7\end{array}$

15 Our monitoring and evaluation mechanisms are effective in tracking the projects.

$\begin{array}{lllllll}1 & 2 & 3 & 4 & 5 & 6 & 7\end{array}$

16 The organization invests in capacity-building training $\begin{array}{lllllllll}\text { programs for developing our PM knowledge and skills. } & 1 & 2 & 3 & 4 & 5 & 6 & 7\end{array}$

17 We are accustomed to having several formal meetings to discuss and share projects experiences. $\begin{array}{lllllll}1 & 2 & 3 & 4 & 5 & 6 & 7\end{array}$

18 We have very effective project communication systems and technology.

19 The organizational project culture is well-defined and promotes project works within an organization.

$\begin{array}{lllllll}1 & 2 & 3 & 4 & 5 & 6 & 7\end{array}$ 


\section{C: Collaborative Social PM Resource}

Collaborative social PM resource can be a process of participation outside the organisation through which people, groups and organisations work together to share PM knowledge and skills to achieve the desired results. PM knowledge can be shared through formal or informal ways of interactions with external bodies.

\section{Collaborative Social PM Resource}

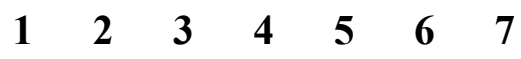

21 We receive highly important support for our projects from government bodies, including advisory and $\begin{array}{llllllll}1 & 2 & 3 & 4 & 5 & 6 & 7\end{array}$ technical support.

22 Project donors support us through meetings, $\begin{array}{llllllll}\text { discussions and standard manuals. } & 1 & 2 & 3 & 4 & 5 & 6 & 7\end{array}$

23 NGOs' Intra forums and consortium meetings help us to share project experiences amongst the staff of NGOs.

$\begin{array}{lllllll}1 & 2 & 3 & 4 & 5 & 6 & 7\end{array}$

24 We lack official information-sharing among NGOs through websites, social media, and/or other means. $\quad \begin{array}{lllllll}1 & 2 & 3 & 4 & 5 & 6 & 7\end{array}$

25 We have combined projects with other organizations and share our project experiences through formal meetings.

26 Our joint projects with partner organizations promote informal discussions to generate appropriate solutions $\begin{array}{lllllllll}1 & 2 & 3 & 4 & 5 & 6 & 7\end{array}$ to project issues. 
27 Networking relationships, which include face-to-face discussions and informal meetings with stakeholders, help us to share PM knowledge and skills.

28 We have joint discussions and meetings with project $\begin{array}{llllllll}\text { beneficiaries in project cycle activities. } & 1 & 2 & 3 & 4 & 5 & 6 & 7\end{array}$

29 Our project marketing events, such as project awareness and inauguration programs, help us to gather useful knowledge from the community for $\begin{array}{llllllll}1 & 2 & 3 & 4 & 5 & 6 & 7\end{array}$ implementing projects.

30 We participate in our community of practice through

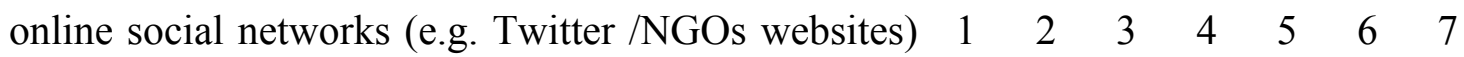
to discuss project issues.

\section{Demographic Information}

Please complete the information below. This demographic information is private and confidential, and analysis will be conducted on the aggregate data only and will not be used on an individual basis.
a. Type of
Organization:

b. Age of Respondent:

\begin{tabular}{|l|l|}
\hline Local NGO & International NGO \\
$\square$ & $\square$ \\
\hline
\end{tabular}

c. Experience in $\mathrm{NGO}$ projects: (Years) 
Type of Project you have been involved in:

(Select one which most suits you)

d. Gender:

e. Education:

(Select the highest level only)

Please provide your

\begin{tabular}{|c|c|c|}
\hline $\begin{array}{l}\text { Livelihoods } \\
\square\end{array}$ & $\begin{array}{l}\text { Health \& Nutrition } \\
\square\end{array}$ & $\begin{array}{l}\text { Capacity Building } \\
\square\end{array}$ \\
\hline $\begin{array}{l}\text { Infrastructure } \\
\square\end{array}$ & $\begin{array}{l}\text { Training / } \\
\square \\
\text { Education }\end{array}$ & $\begin{array}{l}\text { Women } \\
\square \\
\text { Development }\end{array}$ \\
\hline $\begin{array}{l}\text { Relief \& Disaster } \\
\square \\
\text { Management }\end{array}$ & $\begin{array}{l}\text { Protection (Human } \\
\square \\
\text { (Rights, child } \\
\text { protection etc.) }\end{array}$ & $\begin{array}{l}\text { Gender Equity } \\
\square\end{array}$ \\
\hline $\begin{array}{l}\text { Water and } \\
\square\end{array}$ & $\begin{array}{l}\text { Social Mobilization } \\
\square\end{array}$ & $\begin{array}{l}\text { Others } \\
\square\end{array}$ \\
\hline $\begin{array}{l}\text { Batquation } \\
\square\end{array}$ & $\begin{array}{l}\text { Female } \\
\square\end{array}$ & $\begin{array}{l}\text { Please } \\
\text { Specify............. }\end{array}$ \\
\hline $\begin{array}{l}\text { High School } \\
\square\end{array}$ & \multicolumn{2}{|c|}{$\begin{array}{l}\text { Bachelor's Degree } \\
\square\end{array}$} \\
\hline $\begin{array}{l}\text { Postgraduate Degre } \\
\square\end{array}$ & \multicolumn{2}{|c|}{$\begin{array}{l}\text { Doctoral Degree } \\
\square\end{array}$} \\
\hline $\begin{array}{l}\text { Any Project Manag } \\
\text { No } \square \\
\text { Please Specify }\end{array}$ & ment Courses / Certifi & Yes $\square$ \\
\hline
\end{tabular}
Email: 


\section{Appendix 3 - Alternative Three Measurement Models of PM Resources}

\section{CFA Model 1: Three Levels of PM Resources}

The CFA Model 1 is drawn based on the findings of EFA, which identified the best indicators for each factor. The first factor is team PM resource, which consists of eight indicators. The second factor is organisational PM resource, which consists of nine indicators. Finally, the third factor, collaborative social PM resource, consists of eight indicators.

CFA was performed with all the identified indicators. The results for absolute fit indices indicate that normed chi-square ( $\chi^{2} / \mathrm{df}$ ) value is 3.140 , GFI is 0.859 , RMSEA is 0.069 , pclose value is less than 0.05, and SRMR is 0.049. Next, incremental indices results are: NFI is 0.869, TLI is 0.896, and CFI is 0.909. Finally, the parsimonious fit indices results demonstrate that AGFI is 0.831 and PNFI is 0.791 . The results of these three indices demonstrate poor fit of model (Hu and Bentler, 1999; Byrne, 1994; Wheaton, 1987). All the indicators have statistically significant loadings on the factors. AVE values for the latent factors of TPR and OPR are satisfactory and all latent CR values are adequate (Hair et al., 2010). (see Figure 2 and Table 11) 


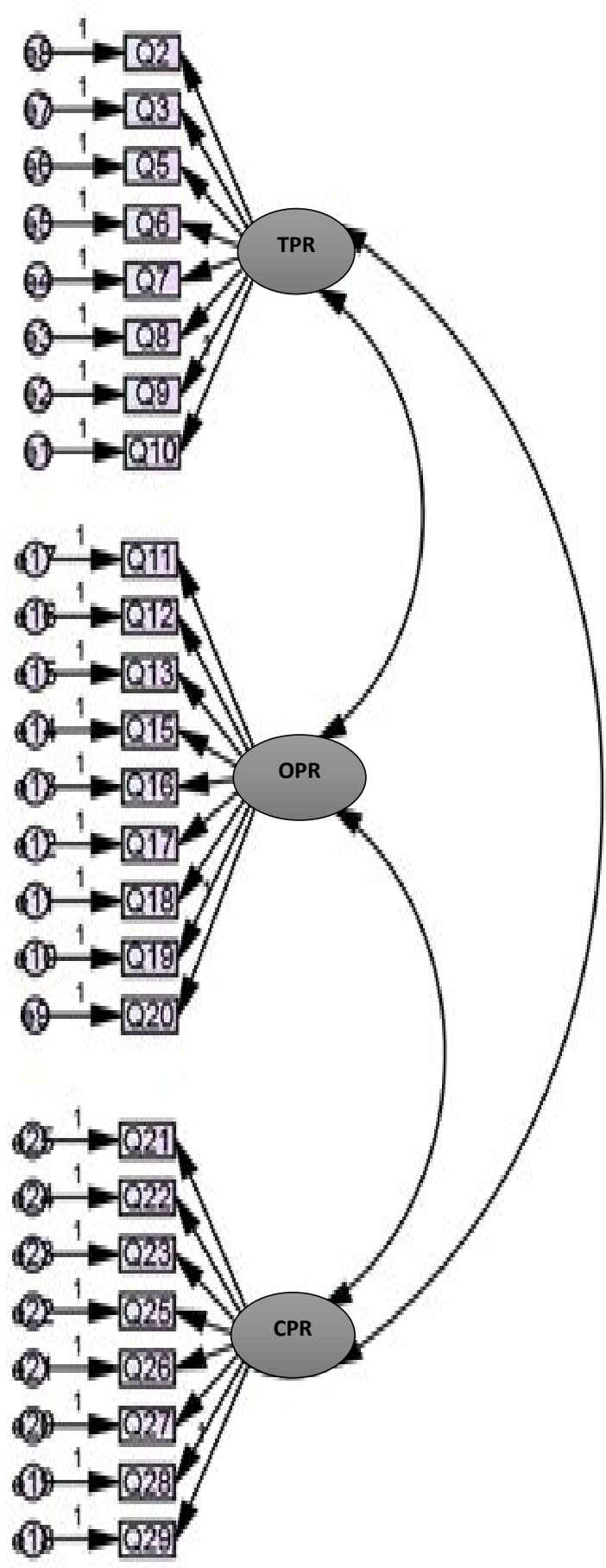

\begin{tabular}{|c|c|c|c|c|}
\hline \multirow[t]{2}{*}{ Construct } & \multirow[t]{2}{*}{ Item } & \multicolumn{3}{|c|}{ Standardised } \\
\hline & & TPR & OPR & CPR \\
\hline \multirow{8}{*}{$\begin{array}{l}\text { Team PM } \\
\text { Resource } \\
\text { (TPR) }\end{array}$} & Q2 & 0.67 & & \\
\hline & Q3 & 0.63 & & \\
\hline & Q5 & 0.62 & & \\
\hline & Q6 & 0.74 & & \\
\hline & Q7 & 0.76 & & \\
\hline & Q8 & 0.81 & & \\
\hline & Q9 & 0.76 & & \\
\hline & Q10 & 0.83 & & \\
\hline \multirow{9}{*}{$\begin{array}{l}\text { Organisational } \\
\text { PM Resource } \\
\text { (OPR) }\end{array}$} & Q11 & & 0.73 & \\
\hline & Q12 & & 0.77 & \\
\hline & Q13 & & 0.79 & \\
\hline & Q15 & & 0.70 & \\
\hline & Q16 & & 0.69 & \\
\hline & Q17 & & 0.72 & \\
\hline & Q18 & & 0.73 & \\
\hline & Q19 & & 0.77 & \\
\hline & Q20 & & 0.77 & \\
\hline \multirow{8}{*}{$\begin{array}{l}\text { Collaborative } \\
\text { Social PM } \\
\text { Resource } \\
\text { (CPR) }\end{array}$} & Q21 & & & 0.53 \\
\hline & Q22 & & & 0.70 \\
\hline & Q23 & & & 0.65 \\
\hline & Q25 & & & 0.56 \\
\hline & Q26 & & & 0.60 \\
\hline & Q27 & & & 0.72 \\
\hline & Q28 & & & 0.72 \\
\hline & Q29 & & & 0.72 \\
\hline AVE & & 0.53 & 0.55 & 0.43 \\
\hline $\begin{array}{l}\text { Construct } \\
\text { Reliability }\end{array}$ & & 0.90 & 0.92 & 0.86 \\
\hline $\begin{array}{l}\text { Absolute Fit } \\
\text { Index }\end{array}$ & \multicolumn{4}{|c|}{$\begin{array}{l}\chi^{2}=854.1, \mathrm{df}=272, \chi^{2} / \mathrm{df} \\
=3.140, \mathrm{GFI}=0.859, \\
\text { RMSEA }=0.069, \text { P-close }< \\
0.05, \mathrm{SRMR}=0.051\end{array}$} \\
\hline $\begin{array}{l}\text { Incremental } \\
\text { Fit Index }\end{array}$ & \multicolumn{4}{|c|}{$\begin{array}{l}\mathrm{NFI}=0.872, \mathrm{TLI}=0.899 \\
\mathrm{CFI}=0.909\end{array}$} \\
\hline $\begin{array}{l}\text { Parsimony Fit } \\
\text { Index }\end{array}$ & \multicolumn{4}{|c|}{$\begin{array}{l}\mathrm{AGFI}=0.831, \mathrm{PNFI}= \\
0.791\end{array}$} \\
\hline
\end{tabular}

Table 11: Estimates for CFA Model 1 


\section{Elimination of Items}

Hair et al. (2006) indicate the statistical significance of an item alone does not indicate the item contributes to the model fit adequately. The factor loadings should be greater than 0.7 and a minimum of 0.5 is acceptable for model consideration (Hair et al., 2010; Byrne, 2010). However, the decision to remove items from the model should be made with consideration of the standardised residual covariance (SRC) values reference with theoretical sides (Hair et al., 2010; Schumaker and Lomax, 2004). Certain ranges are proposed to interpret the standardised residual covariance matrix. SRC values greater than 2.58 are considered to be large (Byrne, 2010) and values greater than 1.96 or 2.58 do not explain the model well (Schumaker and Lomax, 2004).

Table 12 shows the elimination of items consisting of high SRC values in CFA Model 1. The indicators with high SRC values, greater than 1.96, were noted for elimination. High SRCs were found in the first factor Q3 and Q5), second factor (Q15, Q16 and Q19) and in the third factor (Q21 and Q26). Subsequently, these items with high SRCs were eliminated in order to improve the model fit and the alternative model was drawn (Schumaker and Lomax, 2004). 


\begin{tabular}{|c|c|c|c|c|}
\hline \multirow[b]{2}{*}{ Items } & \multirow[b]{2}{*}{$\begin{array}{l}\text { Loading } \\
\qquad \mathrm{s}\end{array}$} & \multicolumn{2}{|c|}{ SRCs } & \multirow[t]{2}{*}{ Elimination and Justification } \\
\hline & & $>1.96$ & $>2.58$ & \\
\hline Q3 & 0.63 & 3 & 0 & $\begin{array}{l}\text { Removed / Moderate loadings + three SRCs }>1.96 \\
\text { (with Q27, Q28, and Q29) }\end{array}$ \\
\hline Q5 & 0.61 & 3 & 0 & $\begin{array}{l}\text { Removed / Moderate loadings + three SRCs }>1.96 \\
\text { (with Q21, Q26 and Q6) }\end{array}$ \\
\hline Q15 & 0.70 & 1 & 0 & $\begin{array}{l}\text { Removed / Moderate loadings + one SRC }>1.96 \\
\text { (with Q28) }\end{array}$ \\
\hline Q16 & 0.69 & 2 & 0 & $\begin{array}{l}\text { Removed / Moderate loadings + two SRCs }>1.96 \\
\text { (with Q28 and 29) }\end{array}$ \\
\hline Q19 & 0.77 & 2 & 0 & $\begin{array}{l}\text { Removed / Good loadings }+ \text { one SRC }>1.96 \text { (with } \\
\text { Q25 and Q23) }\end{array}$ \\
\hline Q21 & 0.54 & 2 & 3 & $\begin{array}{l}\text { Removed / Moderate loadings + two SRCs }>1.96 \\
(\text { with Q5 and Q20) + three SRCs }>2.58 \text { (with Q2, } \\
\text { Q8 and Q23) }\end{array}$ \\
\hline Q26 & 0.60 & 1 & 2 & $\begin{array}{l}\text { Removed / Moderate loadings }+ \text { one SRC }>1.96 \\
(\text { with Q5) + two SRCs }>2.58(\mathrm{Q} 25 \text { and Q27) }\end{array}$ \\
\hline
\end{tabular}

Table 12: Elimination of Items for CFA Model 1

\section{CFA Model 2: Three Levels of PM Resources}

CFA Model 2 comprised screened indicators after the elimination of high SCR indicators in the first stage. In the first factor, team PM resources, the six indicators selected are Q2, Q6, Q7, Q8, Q9 and Q10. In the second factor, organisational PM resources, the six selected items are Q11, Q12, Q13, Q17, Q18 and Q20. In the third factor, collaborative social PM resources, the six items are Q22, Q23, Q25, Q27, Q28 and Q29.

The results of absolute fit indices show that normed chi-square $\left(\chi^{2} / \mathrm{df}\right)$ value is 2.742 , GFI is 0.911 , RMSEA is 0.063 , p-close value is less than 0.05 and SRMR is 0.041 . Incremental indices results show that NFI is 0.922 , TLI is 0.940 and CFI is 0.948 . The parsimonious fit indices results indicate that AGFI is 0.884 and PNFI is 0.795 . The fit indices show a 
mediocre fit (Hu and Bentler, 1999; Byrne, 1994; Wheaton, 1987). AVE values for the latent factors of TPR and OPR are satisfactory and all latent CR values are good (Hair et al., 2010; Farrell, 2010) (see Figure 3 and Table 13). 


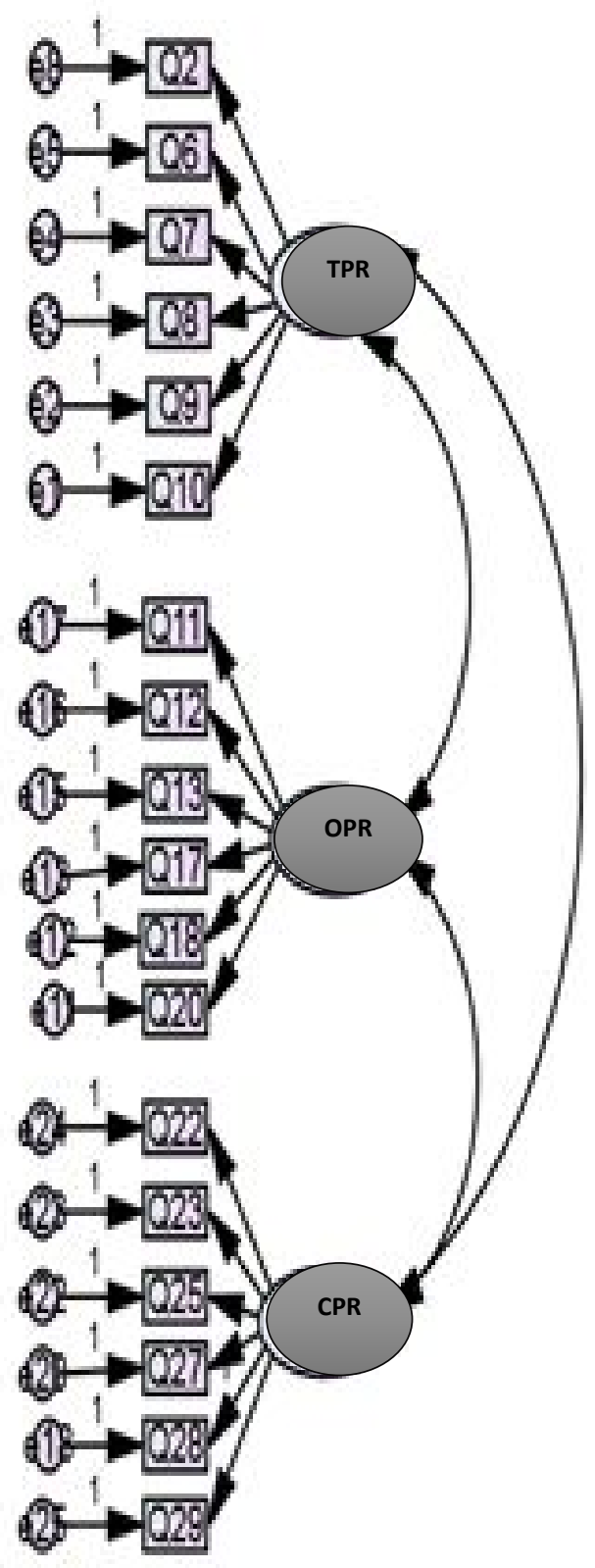

Figure 3: CFA Model 2

\begin{tabular}{|c|c|c|c|c|}
\hline \multirow[t]{2}{*}{ Construct } & \multirow[t]{2}{*}{ Item } & \multicolumn{3}{|c|}{ Standardised } \\
\hline & & TPR & OPR & CPR \\
\hline \multirow{6}{*}{$\begin{array}{l}\text { Team PM } \\
\text { Resource } \\
\text { (TPR) }\end{array}$} & Q2 & 0.67 & & \\
\hline & Q6 & 0.73 & & \\
\hline & Q7 & 0.77 & & \\
\hline & Q8 & 0.82 & & \\
\hline & Q9 & 0.76 & & \\
\hline & Q10 & 0.83 & & \\
\hline \multirow{6}{*}{$\begin{array}{l}\text { Organisational } \\
\text { PM Resource } \\
\text { (OPR) }\end{array}$} & Q11 & & 0.75 & \\
\hline & Q12 & & 0.79 & \\
\hline & Q13 & & 0.80 & \\
\hline & Q17 & & 0.72 & \\
\hline & Q18 & & 0.72 & \\
\hline & Q20 & & 0.76 & \\
\hline \multirow{6}{*}{$\begin{array}{l}\text { Collaborative } \\
\text { Social PM } \\
\text { Resource (CPR) }\end{array}$} & Q22 & & & 0.70 \\
\hline & Q23 & & & 0.64 \\
\hline & Q25 & & & 0.53 \\
\hline & Q27 & & & 0.70 \\
\hline & Q28 & & & 0.74 \\
\hline & Q29 & & & 0.73 \\
\hline $\begin{array}{l}\text { Average } \\
\text { Variance } \\
\text { Extracted } \\
\text { (AVE) }\end{array}$ & & 0.59 & 0.57 & 0.46 \\
\hline $\begin{array}{l}\text { Construct } \\
\text { Reliability (CR) }\end{array}$ & & 0.89 & 0.89 & 0.83 \\
\hline $\begin{array}{l}\text { Absolute Fit } \\
\text { Index }\end{array}$ & \multicolumn{4}{|c|}{$\begin{array}{l}\chi^{2}=362.0, \mathrm{df}=132, \chi^{2} / \mathrm{df} \\
=2.742, \mathrm{GFI}=0.911, \\
\text { RMSEA }=0.063, \mathrm{p} \text {-close }< \\
0.05, \mathrm{SRMR}=0.041\end{array}$} \\
\hline $\begin{array}{l}\text { Incremental Fit } \\
\text { Index }\end{array}$ & \multicolumn{4}{|c|}{$\begin{array}{l}\mathrm{NFI}=0.922, \mathrm{TLI}=0.940 \\
\mathrm{CFI}=0.948\end{array}$} \\
\hline $\begin{array}{l}\text { Parsimony Fit } \\
\text { Index }\end{array}$ & \multicolumn{4}{|c|}{$\begin{array}{l}\mathrm{AGFI}=0.884, \mathrm{PNFI}= \\
0.795\end{array}$} \\
\hline
\end{tabular}

Table 13: Estimates for CFA Model 2 


\section{Elimination of Items for CFA Model 2}

CFA Model 2 presents all the indicators which have SRCs less than 1.96. However, the CFA model is not a good fit. Therefore, the modification index (MI) was applied in order to improve the CFA model fit (Whittaker, 2012; MacCallum et al., 1992). Modification indices estimate the extent to which model fit would improve through reducing specification errors (Whittaker, 2012). Specification errors occur due to the inclusion of irrelevant relations or the exclusion of relevant relations (MacCallum, 1986).

Table 14 displays the regression weights of the indicators and factors of CFA Model 2. Some items have high cross-loading many times with other factor items and these items were considered for elimination in order to improve the model fit (Whittaker, 2012; Luijben and Boomsma, 1988). Items Q9, Q20 and Q28 respectively were considered for elimination from team, organisational and collaborative social PM resource. 


\begin{tabular}{|c|c|c|c|c|}
\hline \multicolumn{3}{|c|}{ Highly Cross-loaded Items } & \multirow{2}{*}{$\begin{array}{l}\text { MI } \\
6.331\end{array}$} & \multirow{2}{*}{$\begin{array}{c}\text { Action Taken and Justification } \\
\text { Q9 highly cross-loaded with other factor }\end{array}$} \\
\hline Q9 & $<---$ & Q25 & & \\
\hline Q9 & $<---$ & Q11 & 6.379 & items. \\
\hline Q9 & $<---$ & Q12 & 11.326 & \\
\hline Q9 & $<---$ & Q13 & 4.527 & Removed Item Q9 \\
\hline Q9 & $<---$ & Q18 & 6.121 & \\
\hline Q9 & $<---$ & Q2 & 9.321 & \\
\hline Q20 & $<---$ & Q29 & 6.131 & Q20 highly cross-loaded with other factor \\
\hline Q20 & $<---$ & Q7 & 5.902 & items. \\
\hline Q20 & $<---$ & Q8 & 5.836 & \\
\hline Q20 & $<---$ & Q10 & 5.972 & Removed Item Q20 \\
\hline Q28 & $<---$ & Q23 & 6.219 & Q28 highly cross-loaded with other factor \\
\hline Q28 & $<---$ & Q13 & 6.746 & items. \\
\hline Q28 & $<---$ & Q17 & 4.366 & \\
\hline Q28 & $<---$ & Q06 & 7.878 & Removed Item Q28 \\
\hline
\end{tabular}

Table 14: Modification Index: Regression Weights - CFA Model 2 


\section{CFA Model 3: Three Levels of PM Resources}

Model 3 consists of screened indicators after the elimination of highly cross-loaded indicators. Team PM resource consists of five items: Q2, Q6, Q7, Q8 and Q10; organisational PM resources consists of five items: Q11, Q12, Q13, Q17 and Q18 and collaborative social PM resource consists of five items: Q22, Q23, Q25, Q27 and Q29.

The results of absolute fit indices produce a normed chi-square ( $x 2 / \mathrm{df})$ value of 2.210, GFI is 0.947, RMSEA is 0.052, p-close value is greater than 0.05 and SRMR is 0.037 . Incremental indices results show that NFI is 0.945, TLI is 0.963 and CFI is 0.969. Parsimonious fit indices results indicate that AGFI is 0.927 and PNFI is 0.783 . The fit indices give average values for the acceptable level of fit (Hu and Bentler, 1999; Byrne, 1994; Wheaton, 1987). AVE values for the latent factors of TPR and OPR are satisfactory and all latent CR values are very good (Hair et al., 2010; Farrell, 2010) (See Figure 4 and Table 15). 


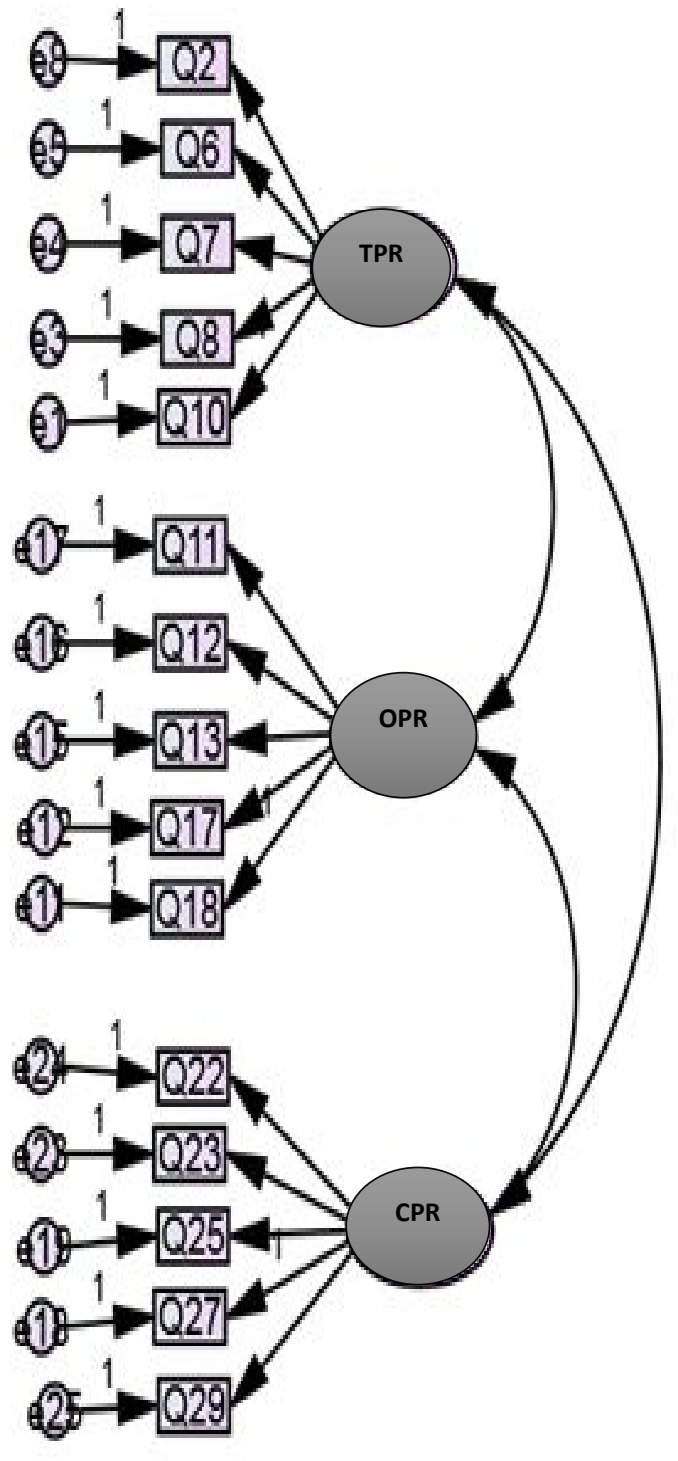

Figure 4: CFA Model 3

\begin{tabular}{|c|c|c|c|c|}
\hline \multirow[t]{2}{*}{ Construct } & \multirow[t]{2}{*}{ Item } & \multicolumn{3}{|c|}{ Standardised Factor } \\
\hline & & TPR & OPR & CPR \\
\hline \multirow{5}{*}{$\begin{array}{l}\text { Team PM } \\
\text { Resource } \\
\text { (TPR) }\end{array}$} & Q2 & 0.70 & & \\
\hline & Q6 & 0.75 & & \\
\hline & Q7 & 0.78 & & \\
\hline & Q8 & 0.83 & & \\
\hline & Q10 & 0.80 & & \\
\hline \multirow{5}{*}{$\begin{array}{l}\text { Organisational } \\
\text { PM Resource } \\
\text { (OPR) }\end{array}$} & Q11 & & 0.77 & \\
\hline & Q12 & & 0.81 & \\
\hline & Q13 & & 0.80 & \\
\hline & Q17 & & 0.71 & \\
\hline & Q18 & & 0.72 & \\
\hline \multirow{5}{*}{$\begin{array}{l}\text { Collaborative } \\
\text { Social PM } \\
\text { Resource } \\
\text { (CPR) } \\
\end{array}$} & Q22 & & & 0.71 \\
\hline & Q23 & & & 0.67 \\
\hline & Q25 & & & 0.53 \\
\hline & Q27 & & & 0.72 \\
\hline & Q29 & & & 0.71 \\
\hline $\begin{array}{l}\text { Average } \\
\text { Variance } \\
\text { Extracted } \\
\text { (AVE) }\end{array}$ & & 0.60 & 0.58 & 0.45 \\
\hline $\begin{array}{l}\text { Construct } \\
\text { Reliability } \\
\text { (CR) }\end{array}$ & & 0.88 & 0.87 & 0.80 \\
\hline $\begin{array}{l}\text { Absolute Fit } \\
\text { Index }\end{array}$ & \multicolumn{4}{|c|}{$\begin{array}{l}x^{2}=192.2, \mathrm{df}=87, x^{2} / \mathrm{df}= \\
2.210, \mathrm{GFI}=0.947, \mathrm{RMSEA}= \\
0.52, \mathrm{p}-\text { close }>0.05, \mathrm{SRMR}= \\
0.037\end{array}$} \\
\hline $\begin{array}{l}\text { Incremental } \\
\text { Fit Index }\end{array}$ & \multicolumn{4}{|c|}{$\begin{array}{l}\mathrm{NFI}=0.945, \mathrm{TLI}=0.963, \mathrm{CFI} \\
=0.969\end{array}$} \\
\hline $\begin{array}{l}\text { Parsimony Fit } \\
\text { Index }\end{array}$ & \multicolumn{4}{|c|}{$\mathrm{AGFI}=0.927, \mathrm{PNFI}=0.783$} \\
\hline
\end{tabular}

Table 15: Estimates for CFA Model 3 


\section{Elimination of Items for CFA Model 3}

Table 16 contains the regression weights of indicators and factors of CFA Model 3. Model 3 shows the fit is reasonable for acceptance. To improve the model further and fix the overestimation of indicators (Hair et al., 2006), three more highly cross-loaded items, Q10, Q17 and Q25 respectively, from team, organisational and collaborative social PM resources have been considered for elimination.

\begin{tabular}{|l|c|l|}
\hline Highly Cross-loaded Items & MI & \multicolumn{1}{|c|}{ Action Taken and Justification } \\
\hline Q10 <--- Q27 & 4.741 & Q10 highly cross-loaded with other factor \\
Q10<--- Q12 & 4.513 & items. \\
Q10 <--- Q13 & 8.037 & \\
Q10 <--- Q18 & 4.495 & Removed Item Q10 \\
& & \\
\hline Q17<--- Q29 & 5.725 & Q17 highly cross-loaded with other factor \\
Q17 <--- Q12 & 5.655 & items. \\
Q17<--- Q2 & 4.961 & Removed Item Q17 \\
& & \\
\hline Q25 <--- Q18 & 5.872 & Q25 highly cross-loaded with other factor \\
Q25 <--- Q12 & 5.998 & items \\
& & Removed Q25 \\
\hline
\end{tabular}

Table 16: Modification Index: Regression Weights - CFA Model 3 


\begin{tabular}{|c|c|}
\hline Reviewers' Comments & Respond to the Reviewers \\
\hline $\begin{array}{l}\text { 1. From my point of view the research problem is not clearly } \\
\text { stated. Is it that NGO project performance is weak in } \\
\text { international development settings and in particular post- } \\
\text { conflict settings? If yes, give the reader a sense of how worse it } \\
\text { is... Then, is it that there is a lack of knowledge on PM resource } \\
\text { profiles for NGOs in charge of the delivery of these post- } \\
\text { conflict projects? Saying that there is little to no empirical } \\
\text { research done on PM resource profiles in international } \\
\text { development NGOs without any background is a bit contrived. } \\
\text { Please tell us what the knowledge gap (what we are yet to know) } \\
\text { is and what the knowledge stock (what we know) is about the } \\
\text { subject topic? }\end{array}$ & $\begin{array}{l}\text { Thank you, the comment, The aim of this study is to empirically } \\
\text { examine the configuration of project resources in organizations } \\
\text { operating in a post-conflict country environment. Our current } \\
\text { knowledge stock is based on an examination of the characteristics of } \\
\text { resources or capabilities held by firms (Appendix 1). This paper fills } \\
\text { a knowledge gap to identify the resource profile composition of a } \\
\text { population of a specific type of organization (NGOs) in order to } \\
\text { identify the impact of the context on project resource development. }\end{array}$ \\
\hline $\begin{array}{l}\text { 2. What sets apart post-conflict projects from other } \\
\text { international development projects? What does such } \\
\text { specificity mean for managing post-conflict projects including } \\
\text { the development of project resource profiles by the NGOs who } \\
\text { deliver them? On what conceptual grounds, can we suggest } \\
\text { that their project resource profiles are different and what } \\
\text { bearing would this have on their project management? Without }\end{array}$ & $\begin{array}{l}\text { Thank you for the comment. Organizations involved in projects } \\
\text { delivered in post conflict countries have additional responsibilities to } \\
\text { those involved in traditional international development projects due } \\
\text { to the nature of the context. Conflicts can occur in both developed } \\
\text { (Northern Ireland) and developing countries. Post conflict countries } \\
\text { have a history of violence and latent stakeholder tensions that can } \\
\text { return to violence. Organizations need to be sensitive to these } \\
\text { challenges and may need to develop resources and capabilities to }\end{array}$ \\
\hline
\end{tabular}


this conceptual positioning, it would be difficult to see what this research adds to the literature.

3. What makes RBV a good theoretical basis for this paper? How does the RBV theory fit within project settings and is there any work on it? What do we know about RBV application in international development project settings in particular? Without such a discussion, it is difficult to assess the contribution of this paper. I will return to this point. Also, to what extent do NGOs who have resource characteristics hold a competitive advantage in project settings, how and why? And what does this competitive advantage look like in project settings? These questions may deserve your attention if you are to portray a convincing story.

4. Context plays a big role in international development projects and even more in post-conflict situations. Does context play a role at all in this research? Does the context in which post-conflict projects take place has any influence whatsoever on their management? Does it affect the development of project resource profiles and how? What ensure that projects can be delivered without a return to conflict. On a conceptual basis, it suggests that these firms will develop resources that support collaboration rather than competitive advantage.

Thank you for the comment. The RBV is an organization level conceptualization and can be applied to examine the characteristics of firms involved in Projects. Appendix 1 provides a summary of extant work on using the RBV in project firm settings. This work advances existing conceptualizations and empirical work in the RBV by 1) Adopting the penrosean perspective of distinct resource combinations, not individual resource characteristics 2) Identifying the associations among resource characteristics 3) Examining these in the context of firms involved in projects in post conflict environments.

Thank you for the comment. As described earlier, Post conflict
environments are distinct from other developing or developed country
environments. We identified that context may perform a shaping role
as both community and international firms did not significantly differ
in resource profiles. A VRIO/Barney approach would theorize that
international firms may have a higher endowment of formal, codified


makes the Sri Lankan context particular and is there any bearing on your findings? This discussion of context will strengthen the credibility of your findings.

5. Finally, what is the contribution of this research? To what extent does existing research supports or contradicts its findings? As its stands, the discussion focuses on a contrast between Barney and Penrose, which is great. Well done! But again we are in a project context and in particular, an international development project setting. The discussion should focus on that peculiar literature, which is deadly missing. For example, the finding that it is resource combinations, rather than individual resource characteristics, which support the delivery of project activities by NGOs is interesting. But the real question is whether the project context plays a role. resources which would form the basis of their "competitive advantage". In the context of Sri Lanka, both community and international organizations had similar resource profiles.

Thank you for the comment. This work advances existing work to make two contributions to the literature on the Resource Based view in Project Management. The first is that it identifies that resource combinations, a Penrose perspective rather than resource types may support organizational operational project capabilities. The second is that it identifies the possible impact of the post conflict country context on the project resources and capabilities of firms. 